\title{
DIGITALCOMMONS
}

@WAYNESTATE-

Wayne State University

Law Faculty Research Publications

Law School

$1-1-2017$

\section{Trafficking Rescue Initiatives as State Violence}

Sabrina Balgamwalla

Wayne State University

Follow this and additional works at: https://digitalcommons.wayne.edu/lawfrp

Part of the Law and Society Commons

\section{Recommended Citation}

Sabrina Balgamwalla, Trafficking Rescue Initiatives as State Violence, 122 Penn St. L. Rev. 171, 216 (2017)

This Article is brought to you for free and open access by the Law School at DigitalCommons@WayneState. It has been accepted for inclusion in Law Faculty Research Publications by an authorized administrator of DigitalCommons@WayneState. 


\title{
Trafficking Rescue Initiatives as State Violence
}

\author{
Sabrina Balgamwalla*
}

\begin{abstract}
In the last several years, the anti-domestic violence movement has gradually moved away from initial state response policies mandating arrest and prosecution of aggressors. Scholars and advocates argued that these forms of state intervention, which were intended to protect survivors, in fact deprived them of meaningful choices and potentially put them in greater fear or danger. Ironically, as the anti-domestic violence movement sought to disentangle itself from law enforcement, the criminalization of human trafficking offenses empowered law enforcement interventions that could be criticized on similar grounds. This article compares experiences of domestic violence and trafficking survivors and their interactions with law enforcement. Though domestic violence and trafficking law share common policy history, the justice system now responds to these offenses very differently; trafficking survivors are often treated as "victimoffenders" who may be punished rather than protected. The typologies of emotional abuse developed by Professor Linda Mills to frame experiences of domestic violence survivors also suggest that trafficking survivors might comparably experience law enforcement "rescue" interventions as violence. The article concludes that, as in the case of the domestic violence movement, policies that support survivor autonomy and safety are the most promising for survivor protection and trafficking prevention.
\end{abstract}

\footnotetext{
*Assistant Professor of Law, University of North Dakota. This article benefitted tremendously from the input of Leigh Goodmark and participants of the 2016 Immigration Law Teachers Workshop, especially commentator Jaya Ramji-Nogales. The author also wishes to thank UND colleagues and early readers Laura Hand and Del Quest, as well as Grant Christensen, David Haberman, Kit Johnson, Anne Mostad-Jensen, and Tammy Oltz for their thoughtful feedback in the UND Law Faculty Scholarship Series. As always, many thanks to Lauren Harper, whose constant love and support makes all things possible.
} 


\section{Table of Contents}

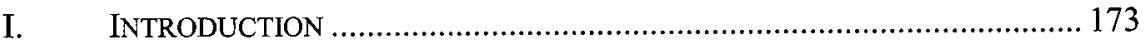

II. DOMESTIC VIOLENCE AND TRAFFICKING .................................... 174

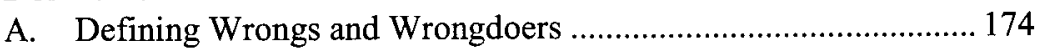

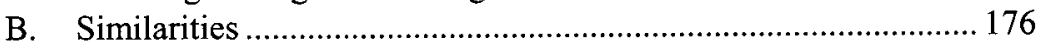

1. Trafficking and Domestic Violence as Relationship-Based

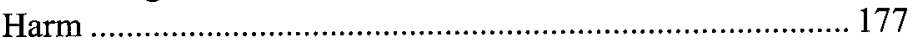

2. Relationships Characterized by Dynamics of Power and

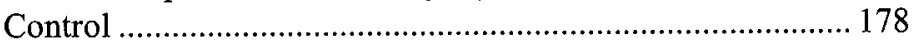

3. Effects on Mental Health ..................................................... 179

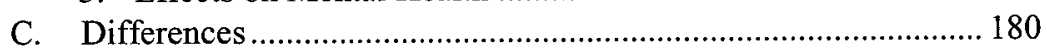

1. Presence of Interpersonal Violence .................................... 180

2. Role of Coercive Control ...................................................... 181

III. CONSTRUCTING STATE RESPONSES TO HUMAN TRAFFICKING.............. 182

A. Parallel Frameworks: Criminalization and Carceral Feminism ... 182

1. State Intervention Responses to Domestic Violence and Human Trafficking........................................................... 183

2. Violence as Gender-Based Harm ...................................... 184

3. Emphasis on Prosecution as a Solution ................................. 185

B. The Violence of Mandatory Intervention.................................... 186

IV. TYPOLOGIES OF EMOTIONAL ABUSE AND "RESCUE" INTERVENTIONS

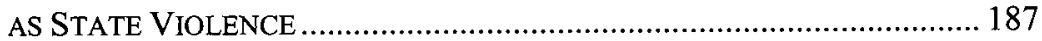

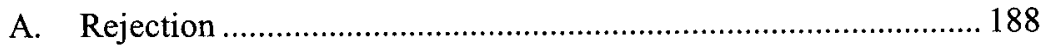

1. Rejection as Emotional Abuse .......................................... 188

2. Rejection in State Interventions: Failure to Identify or Believe Survivors ........................................................... 190

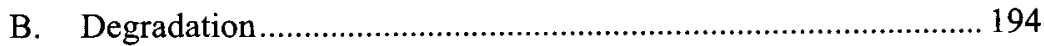

1. Degradation as Emotional Abuse........................................ 194

2. Degradation in State Interventions: Police Misconduct and Forced Testimony ............................................................... 195

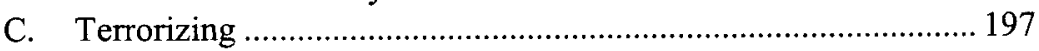

1. Terrorizing as Emotional Abuse ......................................... 197

2. Terrorizing in State Interventions: Raids and Compulsion

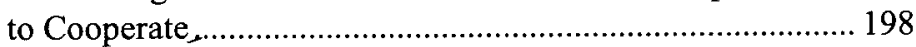

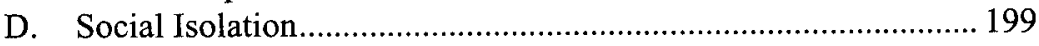

1. Social Isolation as Emotional Abuse....................................... 199

2. Social Isolation in State Interventions: Undermining

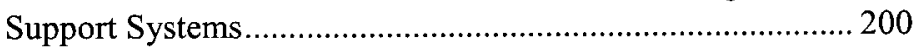

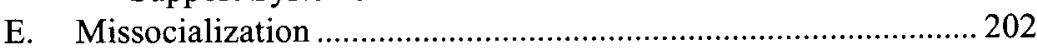

1. Missocialization as Emotional Abuse ................................ 202

2. Missocialization in State Interventions: Solidifying

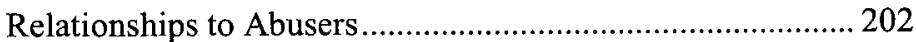

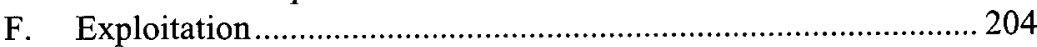

1. Exploitation as Emotional Abuse ........................................ 204 
2. Exploitation in State Interventions: Prosecuting to "Send a Message".

G. Emotional Unresponsiveness .............................................. 206

1. Emotional Unresponsiveness as Emotional Abuse ................ 206

2. Emotional Unresponsiveness in State Interventions: Forced Separation

H. Close Confinement.

1. Close Confinement as Emotional Abuse.

2. Close Confinement in State Interventions: Detention and Incarceration of Victims.

V. Policy IMPLICATIONS: ReCASting THE StATE RESPONSE to HUMAN TRAFFICKING

A. Recognizing the Significance of Relationships and Support Systems

B. Preserving Survivor Autonomy

C. Undoing the Criminalization Paradigm

VI.

CONCLUSION

\section{INTRODUCTION}

Four decades ago, a critical debate emerged within the battered women's movement. After many years of fighting treatment of domestic violence as a "private matter," advocates supported initiatives to ensure that these incidents were taken seriously and that law enforcement would respond to a survivor's call for help. Domestic violence was criminalized as a means of enlisting law enforcement in victim protection. However, advocates soon found that not all survivors wanted to see their partners arrested and prosecuted. State intervention policies-including mandatory arrests and no-drop prosecutions-have since been recognized as potentially alienating women and men who wish to live free of violence, but on their own terms. ${ }^{1}$

Law enforcement officers and prosecutors now struggle with another challenging role: providing assistance to individuals who have experienced sex or labor trafficking, many of whom have reservations about the arrest or prosecution of those implicated in their trafficking. This article compares experiences of domestic violence and trafficking survivors and their experiences with law enforcement, observing that law enforcement intervention policies have played similar roles in both areas with comparable results. State criminalization of human trafficking

1. See infra Part III.A. See generally Deborah Epstein, Procedural Justice: Tempering the State's Response to Domestic Violence, 43 WM. \& MARY L. REV. 1843 (2002); Leigh Goodmark, Autonomy Feminism: An Anti-Essentialist Critique of Mandatory Interventions in Domestic Violence Cases, 37 FLA. ST. U. L. REV. 1 (2009); Tara Urs, Coercive Feminism, 46 Colum. HuM. RTS. L. REv. 85 (2014). 
offenses places the responsibility on law enforcement and the judicial system to identify survivors and punish offenders. Trafficking survivors, like domestic violence survivors, may have a deeply ambivalent relationship with law enforcement agents and institutions and thus may be unwilling to assist or otherwise cooperate with law enforcement officials. ${ }^{2}$

Professor Linda Mills has explored how mandatory law enforcement intervention in domestic violence cases actually constitutes a form of state violence, paralleling the experience of emotional abuse involved in domestic violence and further harming and alienating survivors. ${ }^{3}$ This article argues that state intervention dynamics intended to "rescue" trafficking victims can similarly mirror the coercive dynamics of that individual's exploitation. It concludes that critical perspectives on law enforcement intervention in domestic violence may provide useful insights to address the unintentional harms of law enforcement anti-trafficking initiatives, and reinforce the need for alternative policies that prioritize survivor agency and autonomy.

\section{DOMESTIC VIOLENCE AND TRAFFICKING}

\section{A. Defining Wrongs and Wrongdoers}

Domestic violence is far better understood now than it was 40 years ago. Once considered a husband's right within a marriage, intimate partner violence is now widely understood as a life-threatening phenomenon worthy of the state's attention. Many people now appreciate that domestic violence is not only physical in nature, but may include emotional, psychological, and financial harm perpetrated as a means of control or intimidation. ${ }^{4}$ Although the prototypical domestic violence victim is a woman, there is greater awareness that men can also be subjected to domestic violence and that transgendered people are in fact at great risk of violence in their relationships. ${ }^{5}$ Domestic violence occurs in romantic

2. See, e.g., Aya Gruber et al., Penal Welfare and the New Human Trafficking Intervention Courts, 68 FLA. L. REV. 1333, 1360 (2016). Gruber et al. explain:

Many prostitution defendants do not consider themselves trafficked and decline to disclose evidence of trafficking, even if doing so is in their legal interest. Many defense attorneys urge judges not to describe their clients as trafficked in open court to prevent discomfort, trauma, and even danger, given that the trafficker Id. might be present.

3. See generally Linda G. Mills, Killing Her Softly: Intimate Abuse and the Violence of State Intervention, 113 HARV. L. REV. 550 (1999).

4. See, e.g., Lucke v. Lucke, 300 N.W.2d 231, 234 (N.D. 1980) (concluding that abuse includes mental as well as physical harm).

5. See Leigh Goodmark, Transgender People, Intimate Partner Abuse, and the Legal System, 48 HARV. C.R.-C.L. L. REV. 51, 54-55 (2013). 
same-sex relationships just as it occurs within opposite-sex relationships. ${ }^{6}$ Although biases still exist, many can appreciate, at least theoretically, that individuals subjected to relationship-based violence, as well as individuals who perpetrate such violence, can come from any demographic.

Trafficking law has been in the making for over a hundred years, but has taken on new significance in public discourse in the last two decades. ${ }^{7}$ "Trafficking in persons" is a term with variable public understandings and associations, encompassing an ever-larger number of forms of exploitation. ${ }^{8}$ International law defines trafficking as involving use of "threat or use of force or other forms of coercion, of abduction, of fraud, of deception, of the abuse of power or of a position of vulnerability or of the giving or receiving of payments or benefits to achieve the consent of a person having control over another person" where the goal is exploitation. ${ }^{9}$ The Trafficking Victims Protection Act ${ }^{10}$ (TVPA) in the United States defines "severe trafficking in persons" as "sex trafficking in which a commercial sex act is induced by force, fraud, or coercion, or in which the person induced to perform such act has not attained 18 years of age"11 or "recruitment, harboring, transportation, provision, or obtaining of a person for labor or services, through the use of force, fraud, or coercion for the purpose of subjection to involuntary servitude, peonage, debt bondage, or slavery."'12

The separate categories for sex and other labor trafficking in the TVPA reveal some assumptions about the nature of the offense. In common usage in the United States, the term "trafficking" often refers specifically and exclusively to coerced commercial sex work, ${ }^{13}$ particularly involving juveniles. ${ }^{14} \mathrm{~A}$ number of programs and services established to serve "trafficking survivors" in fact focus only on sex

6. See Taylor N.T. Brown AND Jody L. HERMan, Williams INST., UCLA SCH. OF

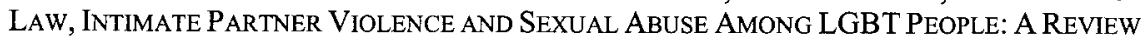
OF EXISTING RESEARCH 2-3 (2015), https://williamsinstitute.law.ucla.edu/wpcontent/uploads/Intimate-Partner-Violence-and-Sexual-Abuse-among-LGBT-People.pdf.

7. See, e.g., Janie A. Chuang, Exploitation Creep and the Unmaking of Human Trafficking Law, 108 AM. J. INT'L L. 609, 609-29 (2014); Jennifer Lynne Musto, What's In a Name? Conflations and Contradictions in Contemporary U.S. Discourses of Human Trafficking, 32 WOMEN's STUD. INT'L FORUM 281, 283 (2009).

8. See, e.g., Chuang, supra note 7, passim.

9. Protocol to Prevent, Suppress and Punish Trafficking in Persons, Especially Women and Children, Supplementing the United Nations Convention against Transnational Organized Crime, Nov. 15, 2000, 2237 U.N.T.S. 319, 344.

10. 22 U.S.C. $\$ 7101(2012)$.

11. Id. $\$ 7102(9)(\mathrm{A})$.

12. Id. $\$ 7102(9)(\mathrm{B})$.

13. See, e.g., Sheldon X. Zhang, Measuring Labor Trafficking: A Research Note, 58 Crime, L. \& Soc. Change 469, 470 (2012).

14. See, e.g., Jennifer Lynne Musto, Domestic Minor Sex Trafficking and the Detention-to-Protection Pipeline, 37 Dialectical ANTHRopology 257, 265 (2013). 
trafficking, and often serve young women exclusively. ${ }^{15}$ New York's Human Trafficking Intervention Courts-problem-solving courts focused on alternatives to criminal prosecution - are entirely devoted to cases of individuals facing prostitution charges. ${ }^{16}$ Labor trafficking survivors, in particular adult men who are not associated with the commercial sex industry, are often excluded from discussions of trafficking altogether. ${ }^{17}$ In the interest of inclusivity, this article will use the TVPA definition of trafficking, with an emphasis on both sex and labor trafficking involving adults.

\section{B. Similarities}

Because the term "human trafficking" is used so broadly to refer to different types of conduct, it is difficult to comprehensively connect research and scholarship in the field. ${ }^{18}$ Nonetheless, there are a number of empirical studies that further our understanding and appreciation of dynamics within trafficking situations. Dominique Roe-Sepowitz, Kristine E. Hickle, Jaime Dahlstedt, and James Gallagher, for example, interviewed a number of domestic violence survivors as well as individuals deemed by law enforcement to be survivors of sex trafficking. ${ }^{19}$ Aya Gruber, Amy J. Cohen, and Kate Mogulescu have analyzed the experiences of defendants in Human Trafficking Intervention Courts in New York City and judges' perceptions of victims and their needs. ${ }^{20}$ In the last five years, there have also been studies based on interviews with trafficking survivors nationwide, ${ }^{21}$ as well as studies

15. See, e.g., Sabrina Balgamwalla, Trafficking in Narratives: Conceptualizing and Recasting Victims, Offenders and Rescuers in the War on Human Trafficking, 94 DENV. L. REV. 1, 19 (2016).

16. See Jonathan Lippman, Announcement of New York's Human Trafficking Intervention Initiative, CTR, FOR COURT INNOVATION (Sept. 25, 2013), http://www. courtinnovation.org/research/announcement-new-yorks-human-trafficking-interventioninitiative.

17. See, e.g. Janie Chuang, Rescuing Trafficking from Ideological Capture, $158 \mathrm{U}$. PA. L. REV. 1655, 1710-12 (2010).

18. See InT'L ORg. For Migration, Data and Research On Human TrafFicking: A Global SuRvey 10-12 (Frank Laczko \& Elzbieta Gozdziak eds., 2005), http://publications.iom.int/system/files/pdf/global_survey.pdf.

19. See generally Dominique E. Roe-Sepowitz et al., Victim or Whore: The Similarities and Differences Between Victim's Experiences of Domestic Violence and Sex Trafficking, 24 J. HUM. BEHAV. IN THE SOC. ENV'T 883 (2014).

20. See Gruber et al., supra note 2, at 1360.

21. See generally Colleen OWens et AL., URban Inst. Justice Policy Ctr. \& Ne. UNIV., UNDERSTANDING THE ORGANIZATION, OPERATION, AND VICTIMIZATION OF LABOR TRAFFICKING IN THE UNITED STATES (2014), http://www.urban.org/sites/default/ files/publication/33821/413249-Understanding-the-Organization-Operation-and-

Victimization-Process-of-Labor-Trafficking-in-the-United-States.PDF. 
focused on labor trafficking in San Diego County ${ }^{22}$ and on the experiences of migrant farmworkers in North Carolina. ${ }^{23}$ Based on these studies, there are similarities between domestic violence and trafficking - as well as key differences-that emerge in comparisons of survivor experiences.

\section{Trafficking and Domestic Violence as Relationship-Based Harm}

Since the 1980s, domestic violence has been defined by the presence of coercive control, where an abuser uses "intimidation, surveillance, degradation, shaming, and isolation" to foster "fear, secrecy, dependence, compliance, and loyalty." 24 This dynamic, however, is not unique to the behavior that is characterized as domestic violence. Judge Toko Serita of the Queens County Human Trafficking Court is among those who have noted abusive dynamics in the prostitution cases in her courtroom, remarking, "I really equate people's reactions to trafficking victims who are in situations of intimate partner violence with their pimp/exploiter in some ways with where we are with domestic violence issues about 30 years ago." 25

Roe-Sepowitz, Hickle, Dahlstedt, and Gallagher have explored similarities between survivors of sex trafficking and domestic violence from the perspectives of survivors, observing that both forms of harm tend to be relationship-based. ${ }^{26} \mathrm{~A}$ "trafficker" may be a pimp, but may also be an employer, supervisor, or recruiter, ${ }^{27}$ depending on the nature of the trafficking scheme. Although the common perception is that traffickers and victims are not known to each other, this is frequently not the case; recruiters often make use of their social networks to find new employees, who can be family members or close family friends. ${ }^{28}$ Victims may also

22. See generally SHeldon X. Zhang, LoOkIng FOR A Hidden POPUlation: TRAFFICKING OF MIGRANT LABORERS IN SAN DIEGO COUNTY (2012), https:// humantraffickinghotline.org/sites/default/files/Looking $\% 20$ for $\% 20 \mathrm{a} \% 20 \mathrm{Hidden} \% 20 \mathrm{Pop}$ ulation\% $20-\% 20$ SDSU_0.pdf.

23. See generally KeLLy BarRick ET AL., NAT'L INST. OF JUST., INDICATORS OF LABOR TRAFFicking AMONG NORTH Carolina Migrant Farmworkers (2013), https://www.ncjrs.gov/pdffiles1/nij/grants/244204.pdf.

24. Leigh Goodmark, A Troubled Marriage: Domestic Violence and the LEGAL SYSTEM 35 (2012).

25. Gruber et al., supra note 2, at 1344.

26. Roe-Sepowitz et al, supra note 19, at 888 ("In sex trafficking, many pimps/traffickers are mothers, uncles, boyfriends, husbands, etc. Some pimps use those known to them, others use the Romeo technique to get the victim to fall in love with them and then 'turn them out' as victims/prostitutes.").

27. Id.; see also OWENS ET AL., supra note 21, at 35.

28. See, e.g., Laura María Agustín, Sex at the Margins: Migration, Labour MARKETS AND THE RESCUE INDUSTRY 1 (2007); Maite Verhoeven et al., Relationships Between Suspects and Victims of Sex Trafficking. Exploitation of Prostitutes and Domestic 
be groomed through intimate partner relationships, or develop intimate or other kinship relationships with others in the trafficking scheme. ${ }^{29}$ The relationships, as well as accompanying feelings of affection, attachment, or obligation, are often part of the trafficking dynamic. ${ }^{30}$

\section{Relationships Characterized by Dynamics of Power and Control}

As in domestic violence situations, human trafficking relationships are characterized by power differentials. ${ }^{31}$ The dynamics of power and control, central to the Duluth Model of domestic violence, are commonly illustrated via the "Power and Control Wheel"- - a diagram that explains how abusers assert control in various aspects of a victim's life. ${ }^{32}$ The diagram has since been adapted for use in anti-trafficking education efforts. The Trafficking Power and Control Wheel refers to physical, sexual, and emotional abuse in addition to coercion and threats; intimidation; isolation; denying, blaming and minimizing; and using privilege. ${ }^{33}$

Both sex and labor trafficking are defined by the use of intimidation and coercion. ${ }^{34}$ Judge Fernando Camacho of New York's $10^{\text {th }}$ Judicial District has noted similarities between the domestic violence and prostitution offenses in his courtroom: "I think the domestic violence area helped me understand why victims act in certain ways and how batterers are able to control their victims' behavior, using different mechanisms and different techniques. ${ }^{~} 35$ Although the dynamics within a trafficking situation can vary, both sex trafficking and labor trafficking involve power

Violence Parallels in Dutch Trafficking Cases, 21 EUR. J. CRIM. POL'Y RES. 49, 50-51 (2015); Kay B. Warren, Troubling the Victim/Trafficker Dichotomy in Efforts to Combat Human Trafficking: The Unintended Consequences of Moralizing Labor Migration, 19 IND. J. Global Legal StUd. 105, 114 (2012).

29. Roe-Sepowitz et al., supra note 19, at 890; see also Rose Broad, 'A Vile and Violent Thing': Female Traffickers and the Criminal Justice Response, 55 BRIT. J. CRIMINOLOGY 1058, 1066-68 (2015) (describing the role of intimate partnerships in motivating female traffickers' leveraging of acquaintance networks in recruitment); Alexandra F. Levy, Innocent Traffickers, Guilty Victims: The Case for Prosecuting SoCalled 'Bottom Girls' in the United States, 6 ANTI-TRAFFICKING REV. 130, 131 (2016) (describing the roles of trafficking victims in trafficking schemes, who are often subject to prosecution despite their own history of exploitation).

30. See supra note 26.

31. Roe-Sepowitz et al., supra note 19, at 889.

32. See What is the Duluth Model?, DOMESTIC Abuse InTERVEntion Programs, http://www.theduluthmodel.org/about/ (last visited July 8, 2017).

33. See id.

34. See, e.g., OWENS ET AL., supra note 21, at 11-12; Elizabeth Hopper \& José Hidalgo, Invisible Chains: Psychological Coercion of Human Trafficking Victims, 1 INTERCULTURAL HUM. RTS. L. REV. 185, 187-88 (2006).

35. Gruber et al,, supra note 2, at 1348-49. 
imbalances and exploitation. Both forms of trafficking often exploit a victim's poverty, ${ }^{36}$ mental disability, ${ }^{37}$ language proficiency, ${ }^{38}$ or immigration status ${ }^{39}$ when inducing them to work or stay in a trafficking scheme.

\section{Effects on Mental Health}

Both domestic violence and trafficking survivors are likely to suffer trauma as a result of their experiences. Researchers, advocates, and mental health providers have long been aware that domestic violence survivors frequently suffer from chronic and sometimes lingering mental health issues. ${ }^{40}$ One study of domestic violence survivors found a strong correlation between psychological abuse and incidence of depression and post-traumatic stress. ${ }^{41}$ In the trafficking context, coercion, threats, and restricted freedom often have effects on the mental health of survivors, even in the absence of egregious physical abuse.$^{42}$ Like domestic violence victims, trafficking victims are likely to experience multiple forms of victimization $^{43}$ and multiple victimizing experiences, ${ }^{44}$ increasing the likelihood of lasting mental health consequences. ${ }^{45}$ Domestic violence and trafficking survivors also show similarities in post-traumatic stress behaviors, such as attachment and relationship issues, substance abuse, and medical issues. ${ }^{46}$

It is also important to consider how systemic factors may contribute to trauma in victims. For example, individuals in the sex trafficking industry may suffer abuse from traffickers, but also in encounters with law enforcement and the justice system, such as harassment and arrest. ${ }^{47}$ Workers may experience harm at the hands of their traffickers, and also

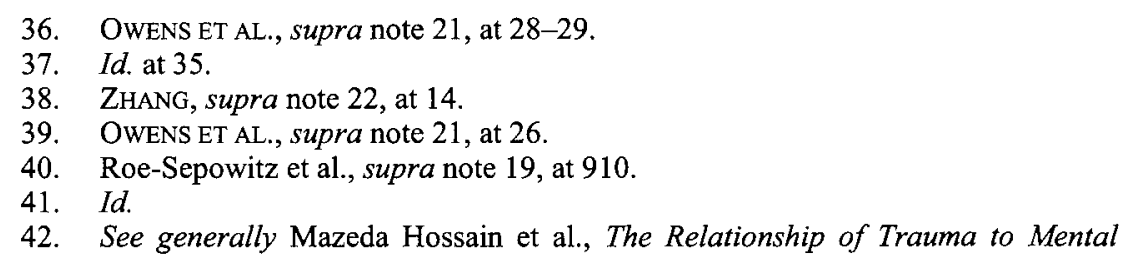
Disorders Among Trafficked and Sexually Exploited Girls and Women, 100 AM. J. PUB. HEALTH 2442 (2010).

43. See OWENS ET AL., supra note 21, at 85 .

44. See id. at 86 .

45. See id. at 150-51; Hossain et al., supra note 42, at 2446; Roe-Sepowitz et al., supra note 19 , at 900 .

46. Roe-Sepowitz et al., supra note 19, at 891.

47. See, e.g., Melissa Ditmore, Urban Justice Ctr. Sex Worker Project, The Use of RaIDS to FIght TRAFFICKING IN PERSONS passim (2009), http:// sexworkersproject.org/downloads/swp-2009-raids-and-trafficking-report.pdf; Rose Corrigan \& Corey S. Shdaimah, People With Secrets: Contesting, Constructing, and Resisting Women's Claims About Sexualized Victimization, 65 CATH. U. L. REV. 429, 434 (2016). 
may be subject to other forms of marginalization in the workplace. ${ }^{48}$ Moreover, individuals with undocumented, temporary, or liminal immigration status may suffer trauma from experiences with immigration officials and local law enforcement exercising immigration detention authority. ${ }^{49}$ Trafficking survivors are often exposed to other such systemic traumas, increasing the likelihood that they will suffer psychological harm.

\section{Differences}

Though survivors of domestic violence and human trafficking have certain experiences in common, domestic violence and sex trafficking are distinct offenses. Domestic violence is defined by the relationship between the offending and offended parties, whereas trafficking is defined by exploitation, although individuals may certainly experience both within the same relationship. ${ }^{50}$ Experiences commonly associated with trafficking-for example, financial exploitation, or close proximity to others who enable or assist the dynamic - may also be present in domestic violence situations, even though they are not typically associated with the offense. $^{51}$ Other differences are subtler, including the nature of the violence between parties and the role that coercive control plays within the dynamic.

\section{Presence of Interpersonal Violence}

Violence and abuse are commonly understood as part of the experience of trafficking survivors. ${ }^{52}$ Even so, while trafficking is characterized by dynamics of harm, it does not always manifest as physical or even interpersonal violence. Trafficking is largely defined by the presence of exploitation, "where another person benefits or gains profits from another person's abuse," 53 whereas domestic violence "is a pattern

48. See, e.g., ZHANG, supra note 22, at 90; Jennifer Chacón, Tensions and TradeOffs: Protecting Trafficking Victims in the Era of Immigration Enforcement, 158 U. PA. L. REV. 1609, 1635 (2010).

49. See generally Leisy J. Abrego \& Sarah M. Lakhani, Incomplete Inclusion: Legal Violence and Immigrants in Liminal Legal Statuses, 37 LAW \& POL'Y 265 (2015) (explaining the precariousness of liminal status); see also Chacón, supra note 48, at 1647.

50. Freedom NeTwork, Human TRAfFicking and DOMEstic Violence 1 (2015), https://freedomnetworkusa.org/app/uploads/2016/12/HT-and-Domestic-Violence.pdf.

51. Roe-Sepowitz et al., supra note 19 , at $890,893$.

52. See, e.g., Nat'l Human Trafficking Res. Ctr., Human Trafficking Power AND CONTROL WHEEL 1, https://humantraffickinghotline.org/sites/default/files/HT\%20 Power\%26Control\%20Wheel $\% 20$ NEW.pdf (noting physical, sexual, and emotional abuse as potential parts of the power and control dynamic within trafficking situations).

53. FREEDOM NETWORK, supra note 50, at 2. 
of abuse in intimate relationships." ${ }^{54}$ Although these practices do not always co-occur, researchers have noted that they are not mutually exclusive. One study observed that sex trafficking and domestic violence survivors reported similar forms of psychological and emotional abuse, such as degradation, shame, threats, and isolation, ${ }^{55}$ as well as experiences of physical violence and resulting injuries. ${ }^{56}$ Those involved in the abolition movement against prostitution have also pointed out the high rates of violence against women in the sex industry. ${ }^{57}$

Although abuse may be present in a trafficking situation, the emphasis on co-occurrence-particularly in the context of sex trafficking-tends to reinforce assumptions about gender-based violence as a whole. Not insignificant in this dynamic is the assumption that trafficking involves the sexual exploitation of women. ${ }^{58}$ Adoption of such a gender-based violence framework has the potential to limit the visibility of certain victims, such as men and boys involved in sex trafficking, as well as many survivors of labor trafficking and exploitation.

\section{Role of Coercive Control}

The concept of "coercive control," long associated with a contemporary understanding of domestic violence, has also become an important part of the legal framework for human trafficking. ${ }^{59}$ Coercive control in trafficking situations is motivated primarily by exploitation and profit $^{60}$ as opposed to intimate relationships, although trafficking and domestic violence may co-exist depending on the relationships between

54. Id. at 1 .

55. Roe-Sepowitz et al., supra note 19, at 889 (noting in particular that similarities between practices include practices of pimps, traffickers, and abusers of "withholding of food and safety, constant instability, erratic and unpredictable moods and swift changes in the location they live").

56. Id. (noting that injuries have been reported by both groups including broken bones, sexual violence, bruises, head injuries, mouth and teeth injuries, stab wounds, vaginal pain and bleeding and also noting that similar to battering, sex trafficking victims reported frequently being struck in the face and head resulting in face, head, mouth, and teeth injuries); see also BARRICK ET AL., supra note 23, at 3-22 (showing rates of physical and sexual abuse as well as threats of physical and sexual abuse by employers); OWENS ET AL., supra note 21, at 81 (giving examples of labor trafficking survivors' responses about harm or threats of harm they experienced).

57. See, e.g., Janice Raymond, Patterns, Profiles and Consequences of Sexual Exploitation, in a COMPaRATIVE StUdy OF WOMEN TRAFFicking IN the Migration Process 54, 60 (2002).

58. Penelope Saunders, Traffic Violations: Determining the Meaning of Violence in Sexual Trafficking Versus Sex Work, 20 J. INTERPERSONAL VIOLENCE 343, 351 (2005).

59. Gruber et al., supra note 2, at 1347.

60. Roe-Sepowitz et al., supra note 19, at 892. 
parties. ${ }^{61}$ Even where trafficking survivors are supporting themselves, sometimes very comfortably, victims do not receive an equitable share of profits. ${ }^{62}$ Economic control frequently plays a large role in the dynamic, as trafficking situations often intentionally foster financial dependence to keep the victim employed within the trafficking scheme. ${ }^{63}$ Coercion in a trafficking situation may also include controlling a victim's housing or access to drugs, or claiming that the victim is bound to the labor arrangement by debt. ${ }^{64}$ Coercion in a domestic violence situation may also threaten a victim's access to basic needs, but not necessarily with an explicitly economic focus.

\section{CONSTRUCTING STATE RESPONSES TO HUMAN TRAFFICKING}

\section{A. Parallel Frameworks: Criminalization and Carceral Feminism}

Despite the fact that domestic violence and trafficking survivors both experience relationship-based, coercive, and traumatizing harm, the justice system treats domestic violence and trafficking cases very differently. The current emphasis on criminalization in trafficking law appears to be informed by the use of mandatory arrest and prosecution that was once part of anti-domestic violence policy. ${ }^{65}$ In the 1990 s, trafficking was framed as part of the larger problem of "gender-based violence," which included domestic violence and prostitution. ${ }^{66}$ In the following decade, as the anti-domestic violence movement raised critical concerns about the mandatory involvement of law enforcement, newly-criminalized trafficking offenses placed law enforcement officers on the front lines to arrest and punish survivors. ${ }^{67}$ Whereas domestic violence law is now more focused on civil protective orders as remedies, state interventions in human trafficking situations often focus on arrest and punishment. ${ }^{68}$

61. See Jean Bruggeman \& Elizabeth Keyes, am. Bar Ass'n, Meeting the LEGAL NEEDS OF HUMAN TRAFFICKING VICTIMS: AN INTRODUCTION FOR DOMESTIC VIOLENCE ATTORNEYS \& ADVOCATES 7-8 (Amanda Kloer, Irena Lieberman \& Robin Runge eds., 2009); FREEDOM NETWORK, supra note 50, at 1-2; DANIELLE MALANGONE \& KATIE CRANK, Ctr. FOR COURT INNOVATION, THE INTERSECTION OF DOMESTIC ViolenCE, SEXUAl AsSAUlt, aND Human TrafFickIng 1, http://www.courtinnovation.org/sites/ default/files/documents/UnderstandingHumanTrafficking_2.pdf.

62. Roe-Sepowitz et al., supra note 19 , at 892.

63. See id.

64. See id.

65. See infra Part III.A.1.

66. See infra Part III.A.2.

67. See infra Part III.A.3.

68. See infra Part III.A.3. 
1. State Intervention Responses to Domestic Violence and Human Trafficking

In the 1980s, a law enforcement-centric policy paradigm emerged in the anti-domestic violence movement following the Minneapolis Domestic Violence Experiment, which concluded that arrests reduced recidivism in domestic violence cases. ${ }^{69}$ As demand for meaningful state responses to domestic violence grew, criminalization and law enforcement intervention became the norm in the United States, driven by state objectives of punishing offenders and rescuing survivors. ${ }^{70}$

With respect to the offense of human trafficking, there has been a similar focus on law enforcement intervention and the prosecution of offenders. ${ }^{71}$ The Trafficking Victims Protection Reauthorization Act of $2008^{72}$ contained an amendment to facilitate the expanded state criminalization of pimping, pandering, and prostitution as trafficking offenses. ${ }^{73}$ Another amendment lessened the government's burden when prosecuting trafficking cases. ${ }^{74}$ State and local governments have since amplified the penalties for those convicted of trafficking offenses, including longer sentences and the required registration of offenders. ${ }^{75}$ The state's response to the offense of human trafficking therefore remains based in criminalization and incarceration.

While such an approach does empower law enforcement to take action on behalf of victims, prosecution can be a fraught process in the context of both domestic violence and sex trafficking. For survivors of exploitation and intimate violence, law enforcement investigations may be imbued with expectations about disclosure and yielding to demands for information and close observation. ${ }^{76}$ Advocates point out that prosecution often occurs in cases where witnesses do not want to testify against their

69. LaWrence W. Sherman \& Richard A. Berk, Police Found., The MinNeapolis DOMESTIC VIOLENCE EXPERIMENT 6-7 (1984), https://www.policefoundation.org/publication/the-minneapolis-domestic-violenceexperiment/.

70. See Leigh Goodmark, Should Domestic Violence Be Decriminalized?, $40 \mathrm{HARV}$. J.L. \& GENDER 53, 65-67 (2017).

71. See Balgamwalla, supra note 15, at 9-13; see also Gruber et al., supra note 2, at $1345-46$.

72. Trafficking Victims Protection Reauthorization Act of 2008, Pub. L. No. 110457,122 Stat. 5044.

73. See id. $\S 225,122$ Stat. at 5072 .

74. See, e.g., 18 U.S.C. $\S 1591$ (2012) (amending the law such that the prosecution need not prove that the defendant knew the victim was under the age of 18 if the defendant had "a reasonable opportunity to observe the [victim]").

75. See Human Trafficking Enactments 2005-2011, NAT'L CONFERENCE OF STATE LegisLATURES, (Dec. 15, 2011), http://www.ncsl.org/research/civil-and-criminaljustice/human-trafficking-laws-in-the-states-updated-nov.aspx.

76. See Corrigan \& Shdaimah, supra note 47 , at 434. 
partners or traffickers. ${ }^{77}$ Such involvement with police and prosecutors may jeopardize a survivor's safety or the safety of his or her family, or present a threat of punishment to someone close to the victim. ${ }^{78}$ Individuals who are not forthcoming or who do not cooperate with law enforcement investigation risk being rendered suspect and having their victimhood questioned. ${ }^{79}$

\section{Violence as Gender-Based Harm}

From a policy perspective, human trafficking law was clearly shaped by the domestic violence discourse of the 1990s. After the passage of the Violence Against Women Act ${ }^{80}$ in the United States in 1994, the Beijing Platform for Action in 1995 specifically addressed human trafficking in the context of the violence against women diagnosis on a global scale. ${ }^{81}$ Domestic violence and trafficking have therefore been linked as genderbased harm, with the presumption that these offenses disproportionately affect women. ${ }^{82}$

Unfortunately, gender-based violence framing sometimes includes gendered assumptions about victims. In her book, A Troubled Marriage, Leigh Goodmark describes the theory of "learned helplessness"-which emerged from experiments involving dogs who were subject to electric shocks and became passive once they realized they could not avoid themand its application to human contexts, including to the behavior of imprisoned and institutionalized individuals, as well as to women subject to domestic violence. ${ }^{83}$ It was later hypothesized that the most effective way to address this phenomenon of learned helplessness was to force women to separate from their partners. ${ }^{84}$ This idea of the passive and prototypically female victim deprived of rationality by abuse still figures prominently in domestic violence discourse. ${ }^{85}$ Critical scholars have observed that human trafficking victims are similarly gendered and often

77. See, e.g., Gruber et al., supra note 2, at 1347; Deborah M. Weissman, The Personal is Political-and Economic: Rethinking Domestic Violence, 2007 B.Y.U. L. REV. 387,400 (2007).

78. See Jennifer Musto, Control and Protect: Collaboration, Carceral Protection, and Domestic SeX Trafficking in the United States 42 (2016).

79. Id.

80. Violence Against Women Act of 1994, Pub. L. No. 103-322, 108 Stat. 1902.

81. U.N. Fourth World Conference on Women, Beijing Declaration and Platform for Action of 1995, Ch. IV.A, Strategic Objective D.3, at 55.

82. See, e.g., Dorchen A. Leidholdt, Prostitution and Trafficking in Women: An Intimate Relationship, 2 J. TRAUMA PRAC. 167, 172-75 (2004).

83. See GOODMARK, supra note 24 , at 57-58.

84. Id. at 58 .

85. See, e.g., Elizabeth MacDowell, Theorizing from Particularity: Perpetrators and Intersectional Theory on Domestic Violence, 16 J. GENDER, RACE \& JUST. 531, 543-44 (2013). 
portrayed as infantile and helpless. ${ }^{86}$ Factors like gender, race, age, and demeanor may affect law enforcement identification of a survivor as a victim or witness, ${ }^{87}$ or conversely, may affect decisions to prosecute the survivor for another offense such as prostitution ${ }^{88}$ or an immigration status violation. ${ }^{89}$

\section{Emphasis on Prosecution as a Solution}

Domestic violence survivors have faced similar expectations that they will choose separation from their partners and cooperate with efforts to prosecute them. ${ }^{90}$ In contemplating the most effective response to domestic violence, states experimented with practices such as mandatory arrests and no-drop prosecutions, which have now been largely abandoned because they deprived victims of choices and had a chilling effect on women's decisions to enlist law enforcement in their protection. ${ }^{91}$ In response to the reluctance of survivors to testify against their partners, states introduced the remedy of civil protection orders, which are intended to provide safety to victims and establish terms for necessary support during a period of separation. ${ }^{92}$

The criminal justice system is frequently ambivalent in its treatment of trafficking survivors. For a survivor of trafficking, and perhaps for some survivors of domestic violence, attendant crimes such as smuggling, immigration fraud, prostitution, and labor violations make for troubled assignation of culpability and liability. ${ }^{93}$ Jennifer Musto describes the law

86. See, e.g., Kamala Kempadoo, Victims and Agents of Crime: The New Crusade Against Trafficking, in GLOBAL LOCKDOWN: RACE, GENDER, AND THE PRISON-INDUSTRIAL COMPLEX 35, 35 (Julia Sudbury ed., 2005); Ratna Kapur, The Tragedy of Victimization Rhetoric: Resurrecting the 'Native' Subject in International/Post-Colonial Feminist Legal Politics, 15 HARV. HuM. RTs. J. 1, 2 (2002); Jayashri Srikantiah, Perfect Victims and Real Survivors: The Iconic Victim in Domestic Human Trafficking Law, 87 B.U. L. REV. 157, 197 (2007).

87. See, e.g., Musto, supra note 14, at 265 (citing law enforcement officer interviews that discuss the prevalence of sex trafficking cases involving juveniles). But see INT'L LABOUR OfFICE, ILO Global Estimate of Forced LabOUR: Results \& MeTHOdOlOGY 13 (2012) (showing labor trafficking offenses to be more common than incidents of sex trafficking).

88. See, e.g., Gruber et al., supra note 2, passim.

89. See generally Jennifer Chacón, Managing Migration Through Crime, 109 COlum. L. Rev. Sidebar 135 (2009).

90. See GOODMARK, supra note 24 , at 64 .

91. See Claire Houston, How Feminist Theory Became (Criminal) Law: Tracing the Path to Mandatory Criminal Intervention in Domestic Violence Cases, $21 \mathrm{MiCH}$. J. GENDER \& L. 217, 255-60 (2014).

92. See, e.g., Margaret Johnson, Redefining Harm, Reimagining Remedies, and Reclaiming Domestic Violence Law, 42 U.C. DAVIS L. REV. 1107, $1111-12$ (2009).

93. See, e.g., Julia O'Connell Davidson, Will the Real Sex Slave Please Stand Up?, 83 FEMINIST REV. 4, 10-11 (2006). 
enforcement response to trafficking as one of "carceral protectionism"that is, "enforcement with a protective bent or carcerality inflected with care." ${ }^{" 94}$ She explains that this framework responds to the precarious legal position of at-risk individuals, treating them as "victim-offenders." 95 Survivors may be theoretically seen as victims in need of protection and support, but once in contact with the justice system, these individuals are subject to scrutiny and condemnation in the same manner as offenders, particularly if they are unwilling to disclose information about the trafficking or testify in court. ${ }^{96}$

This has complicated the prosecution of trafficking; the uneasy relationship between trafficking survivors and the criminal justice system is characterized by low rates of cooperation and regular reluctance among witnesses to testify. ${ }^{97}$ Musto points out that individuals involved in sex trafficking "are discursively caught between competing notions of how victims and offenders ought to behave," and the mechanisms used by the state to address trafficking are similarly fraught. ${ }^{98}$

\section{B. The Violence of Mandatory Intervention}

In her 1999 article, "Killing Her Softly: Intimate Abuse and the Violence of State Intervention," Linda Mills critiqued the law's existing response in domestic violence cases, which included mandatory arrests and no-drop prosecutions. ${ }^{99}$ Mills posited that "the very state interventions designed to eradicate the intimate abuse in battered women's lives all too often reproduce the battering relationship," depriving survivors of meaningful choices and supportive options to keep themselves safe and their emotional lives intact. ${ }^{100}$ Mills's article represented a contribution to the critique of state action as violence, drawing parallels between

94. MUSTo, supra note 78, at 4.

95. Id.

96. Id.

97. See, e.g., Heather J. Clawson et al., ICF Int'L, Prosecuting human Trafficking Cases: Lessons Learned and Promising Practices 20, 24 (2008), https://www.ncjrs.gov/pdffiles 1/nij/grants/223972.pdf; AMY FARRELL ET AL., URBAN INST. Justice and Policy CTR. \& Ne. Univ. Inst. ON RaCe and Justice, IDENTIFYING Challenges to Improve the Investigation and Prosecution of State and Local HUMAN TRAFFICKING CASES 10-11 (2012), https://www.ncjrs.gov/pdffiles $1 /$ nij/grants/ 238795.pdf; Symposium, Sex Work and the Law: Felony, Fetish, or Free Market?, 21 CARDOZO J.L. \& GENDER 499, 513 (2015).

98. See MUSTo, supra note 78 , at 4 .

99. See Mills, supra note 3, at 550.

100. Id. at 554-55. 
emotional abuse and the unintended consequences of state institutions and policies. ${ }^{101}$

Human trafficking policy faces a number of the same challenges as domestic violence law. Both legal frameworks must contemplate factors such as familiar relationships and the presence of personal violence, and possible offenses committed by both parties. In the nationwide and increasingly global movement to criminalize trafficking and punish it as a serious offense, law enforcement has become the conduit for both prosecution and protection of those involved in trafficking situations. ${ }^{102}$ Survivors of sex trafficking, like those who have experienced domestic violence, may attempt to conceal their situations in order to preserve their safety. ${ }^{103}$ Other common reasons for reluctance to involve law enforcement are self-blame and fear of Child Protective Services involvement. ${ }^{104}$ Forcing individuals to come forward and testify undermines their autonomy and calculus of self-preservation. ${ }^{105}$ Accordingly, a growing number of anti-trafficking advocates have questioned the carceral approach to trafficking. ${ }^{106}$

\section{TYPOLOGIES OF EMOTIONAL ABUSE AND "RESCUE" INTERVENTIONS AS STATE VIOLENCE}

In the context of the battered women's movement, law enforcement intervention, arrest, and prosecution of offenders was previously seen as vital for the protection of individuals subjected to abuse. ${ }^{107}$ Given the movement's ambivalence - and internal disagreement-about the role of law enforcement, the state response to domestic violence has retained some of these law enforcement objectives but also includes civil remedies and support services. ${ }^{108}$ Trafficking, however, remains understood largely

101. Id. at 553-54.

102. See, e.g., Balgamwalla, supra note 15, at 3-13 (detailing the criminalization of trafficking in the United States under the TVPA and various state laws); Kempadoo, supra note 86 , at 39-40 (discussing the parallel development of the international anti-trafficking framework and the legal framework to combat organized crime).

103. See Roe-Sepowitz et al., supra note 19 , at 888 .

104. See id.

105. See, e.g., Kimberly D. Bailey, It's Complicated: Privacy and Domestic Violence, 49 AM. CRIM. L. REV. 1777, 1794-1800 (2012).

106. See, e.g., Elizabeth Bernstein, Militarized Humanitarianism Meets Carceral Feminism: The Politics of Sex, Rights, and Freedom in Contemporary Antitrafficking Campaigns, 36 Signs: J. Women IN CULTuRE \& Soc'Y 45, 54-58 (2010); Jennifer Chacón, Misery and Myopia: Understanding the Failures of U.S. Efforts to Stop Human Trafficking, 74 FORDHAM L. REV. 2977, 3019-20 (2006).

107. See, e.g., G. Kristian Miccio, A House Divided: Mandatory Arrest, Domestic Violence, and the Conservatization of the Battered Women's Movement, 42 Hous. L. REV. 237, 264-65 (2005).

108. Johnson, supra note 92 , at 1140-53. 
as criminal activity, which should be punished through the arrest, prosecution, and incarceration of offenders.

In this context, "rescue" embodies the mandatory interventionist approach previously associated with the state's response to domestic violence. State rescue of trafficking victims includes a wide variety of systemic interventions, from Human Trafficking Intervention Courts for individuals facing prostitution charges ${ }^{109}$ to law enforcement raids of brothels and worksites. ${ }^{110}$ In these state initiatives, trafficking survivors may be arrested and taken into custody as witnesses. ${ }^{111}$ In other contexts, trafficked workers may be arrested and detained in relation to immigration status violations. ${ }^{112}$ In some cases, individuals have even been charged as co-conspirators in their own trafficking cases. ${ }^{113}$ Mills's observations about law enforcement interventions as state violence therefore take on powerful new significance in the context of state interventions in human trafficking situations.

\section{A. Rejection}

\section{Rejection as Emotional Abuse}

Mills describes abusive "rejection" behavior in the domestic violence context as "singling the woman out for criticism, punishment, or judgment." 114 For both trafficking and domestic violence victims, criticism and judgment are often a means of exerting control and undermining a victim's sense of self-worth and efficacy. ${ }^{115}$ Trafficking and domestic violence relationships often contain elaborate rules that victims must follow to avoid punishment as a means of fostering submission. ${ }^{116}$ In interviews with survivors of both domestic violence and trafficking, Roe-

109. See, e.g., Gruber et al., supra note 2, 1364-69.

110. See, e.g., John Burnett \& Marisa Peñaloza, How Kitchen Raids In Buffalo Sent Shock Waves Through Immigrant Rights Community, NPR (Jan. 8, 2017, 8:35 AM), http://www.npr.org/2017/01/08/508548698/how-kitchen-raids-in-buffalo-sent-shockwaves-through-immigrant-rights-community; Sebastian Malo, Nearly 500 Arrested in California Human Trafficking Raids, REUTERS (Feb. 1, 2017, 3:18 PM), http://www.reuters.com/article/us-usa-trafficking-arrests-idUSKBN15G5J6.

111. See, e.g., DITMORE, supra note 47, at 45; FARRELL ET AL., supra note 97, at 1011.

112. Musto, supra note 7, at 283; see also Sealing Chang \& Eujung Kim, The Paradoxes of Neoliberalism: Migrant Korean Sex Workers in the United States and 'Sex Trafficking,' 21 SOC. POL.: INT'L STUD. GENDER, ST. \& SOC'Y 355, 361 (2014).

113. See, e.g., Symposium, supra note 97, at 513, 517.

114. See Mills, supra note 3 , at 587.

115. See Roe-Sepowitz et al., supra note 19, at 889.

116. See id. at 891; see also OWENS ET AL., supra note 21, at 81 (citing the example of a worker who, " $[\mathrm{w}]$ hen she made a 'mistake,' was not able to eat for four days ... . [O]nce she took two pieces of chocolate because she was hungry and was forced to stand from 6 a.m. to 4 p.m."). 
Sepowitz et al. found that rejection of a survivor's perspective was a significant aspect of abuse, as many survivors came to doubt their own perspectives after being conditioned to not disclose their situations, including being told that they would not be believed. ${ }^{117}$

Power imbalances are often exploited within domestic violence and trafficking relationships as a means of coercive control. ${ }^{118}$ Survivors may internalize these experiences, humiliated by stigmatizing work and blaming themselves for their choices. ${ }^{119}$ Individuals perpetuating domestic violence or trafficking were also similar in their tendencies to deny wrongdoing and blame victims for their treatment. ${ }^{120}$ Trafficking survivors, like domestic violence survivors, may find themselves threatened with judicial processes that would expose wrongdoing - such as prosecution, deportation, or a child welfare investigation-as part of a dynamic of coercive control. ${ }^{121}$

Individuals subjected to trafficking may suffer additional rejection from others who benefit from their exploitation. In the context of coerced sex work, customers engage in rejection when they do not acknowledge the forced or coerced nature of the work. ${ }^{122}$ Roe-Sepowitz et al. found that many minors subjected to forced prostitution left their situation of their own accord or via intervention by law enforcement, "mean[ing] that throughout the experience [of] being trafficked, the trafficking victim came into contact with men who chose to pay for their services but did not provide a means of escape." 123 This dynamic normalizes the abuse and can reinforce a victim's belief that his or her suffering does not matter and he or she is to blame for the exploitation.

In the context of labor trafficking, rejection can occur in the absence of public awareness or investigation of workplace violence, even where certain industries and markets are dominated by exploitative practices or

117. See Roe-Sepowitz et al., supra note 19, at 890.

118. See id. at 897.

119. See, e.g., Nenette Motus, Int'1 Office on Migration, The Trafficking Process From the Perspective of Trafficking in Persons, in THE MENTAL HEALTH ASPECTS OF TRAFFICKING IN HUMAN BEINGS 31, 37 (2004). Motus observes that trafficking victims often experience "[g]uilt for making a mistake and being naïve, stupid and foolish; for breaking laws of decency and religion (if s/he is a believer), for not succeeding in earning money for his/her family" and "[r]age at his/her own self for 'letting such things happen', at other people, because they did not defend him/her, at her own society and community for letting him/her down, and because his/her life is broken"); see also OWENS ET AL., supra note 21 , at 94 .

120. See Roe-Sepowitz et al., supra note 19, at 890.

121. Seeid.

122. See id. at 893.

123. See id. at 892-93. 
where the trafficking is occurring in plain sight. ${ }^{124}$ This experience is not unlike those of domestic violence survivors who may be pressured by others in their social circles to stay with a partner "for the family's sake," or whose friends and family otherwise fail to acknowledge the abuse or assist the victim. ${ }^{125}$

2. Rejection in State Interventions: Failure to Identify or Believe Survivors

Mills argues that rejection by the state occurs in domestic violence cases where the state actor fails to identify the primary aggressor or ignores the survivor's opinion. ${ }^{126}$ She specifically cites to dual arrest policies, a practice in which law enforcement agents arrest both parties if they cannot identify the primary aggressor. ${ }^{127}$ At one time, many jurisdictions also had "no drop" prosecution policies, wherein the state would pursue charges against an aggressor over a survivor's opinion or preference. ${ }^{128}$ In these situations, a survivor could be seen by the state as a perpetrator or an unreliable or unwilling witness.

In the context of state intervention in trafficking cases, rejection can similarly occur when individuals who are empowered to leave their trafficking situation are not identified as individuals who have been trafficked, or are not believed when they come forward about their experiences. ${ }^{129}$ Certain individuals may be more likely to be identified as

124. See, e.g., OWENS ET AL., supra note 21, at 94-95 (describing experiences of domestic workers who worked for families where the children were encouraged to insult and physically abuse the employee), 96-98 (describing (1) experiences of domestic workers where law enforcement actually came to the house but did not intervene in the trafficking situation; (2) experiences of hotel employees who were sleeping in the storage room, whose condition was known to others working at the hotel who did not intervene; and (3) the experience of a domestic worker who regularly interacted with a neighbor who did not intervene); see also ZHANG, supra note 22, at 11 (finding that the majority (58 percent) of the unauthorized migrant laborers currently in the work force have experienced at least one type of trafficking violation or abusive practice).

125. See Roe-Sepowitz et al., supra note 19, at 893.

126. See Mills, supra note 3, at 589.

127. Id. at 588 .

128. Id. at 589 .

129. Dina Francesca Haynes, Woodrow Wilson Int'l Ctr. for Scholars, Conceptual, Legal and Implementation Gaps in the Protection of Trafficked Persons in the United States, in RETHINKING HUMAN TRAFFICKING 16, 17 (2010), https://www.wilsoncenter.org/ sites/default/files/Rethinking\%20Human\%20Trafficking.pdf; see also Srikantiah, supra note 86 , at 183 . Srikantiah explains:

[T] he regulations... grant preference to victims who are rescued by law enforcement over those who escape from trafficking, a preference that appears nowhere in the statute. Victims whose cases come to light because they escaped from traffickers not only must convince law enforcement to issue an LEA, but also must convince DHS that they could not have left the country after escaping their traffickers. 
survivors or believed when they self-identify. For example, individuals who are young are more likely to be treated as victims, especially if they appear frightened and their cases are reported to law enforcement by credible third parties. ${ }^{130}$ By contrast, individuals who do not fit this profile are less likely to be seen as victims. For example, in a Sex Worker Project study on law enforcement raids, 9 of the 15 sex workers interviewed were previously arrested by local police at least once, often on multiple occasions, and were never identified as trafficking survivors while in law enforcement custody. ${ }^{131}$ One study found that almost one-third of trafficking survivors were initially arrested, most of them because they were initially identified by law enforcement as offenders. ${ }^{132}$

Survivors may also experience rejection if they face expectations that they will self-identify as victims and disclose their exploitation and abuse. These expectations are often conditions for resources and protection, which frequently means "more intrusive demands for the yielding of bodies and narratives to official scrutiny, and performances consistent with expectations about victimization and trauma." ${ }^{133}$ Where trafficking survivors are reluctant to divulge information or submit to the terms of interaction with law enforcement, they are more likely to be pressured into pleading guilty to offenses like prostitution. ${ }^{134}$ Although there are many reasons why trafficking survivors are hesitant to disclose the nature of their situation, research indicates that a primary fear is that they will not be believed. ${ }^{135}$ This fear is reinforced not only by the trafficker, but also by the need for secrecy around engagement in illicit activity. ${ }^{136}$ These authors refer specifically to the context of commercial sex, but this is also true in labor trafficking situations, where individuals are working without authorization or are unlawfully present in the United States and may fear the consequences of removal. ${ }^{137}$

Srikantiah, supra note 86 , at 183.

130. See Roe-Sepowitz et al., supra note 19, at 894; see also Amy Farrell et al., The Prosecution of State-Level Human Trafficking Cases in the United States, 6 ANTrTRAFFICKING REV. 48, 54 (2016) (finding that, among the first generation of state trafficking prosecutions, prosecutors were not familiar with the concept of trafficking beyond the forced prostitution of minors).

131. DITMORE, supra note 47 , at 8.

132. See Farrell et al., supra note 130, at 53.

133. Corrigan \& Shdaimah, supra note 47 , at 434.

134. See, e.g., Suzannah PhIllips et al., City Univ. of N.Y. Sch. OF LaW InT'L Women's Human Rights Clinic, Clearing the Slate: SeEkINg EfFective Remedies FOR CRIMINALIZED TRAFFICKING VICTIMS 18 (2014), http://www.law.cuny.edu/academics/clinics/iwhr/publications/Clearing-the-Slate.pdf.

135. See Roe-Sepowitz et al., supra note 19 , at 888.

136. Id.

137. Chacón, supra note 48, at 1612; see also OWENS ET AL., supra note 21 , at 81 (citing numerous examples in survey responses of employers' threats to call police or immigration officers, send clients to jail, or have them deported). 
With increased reliance on law enforcement to identify victims, jurisdictions that lack specialized units or officers who have received additional training on trafficking are more likely to fail to identify survivors and disbelieve those who self-identify. ${ }^{138}$ In a study by the Urban Justice Center Sex Worker Project, for example, one federal law enforcement agent described his methodology for identifying trafficked individuals as follows:

I would ask them how they got here. I don't have a list of questions. Just all the facts from them about their circumstances. It's not hard to tell. We look at their affect. Usually victims get upset and are frightened. Same as victims of extortion. You can usually tell if they are scared, and that is one of the elements of the crime. If they are not scared, that also tells you something. ${ }^{139}$

Among the local officers interviewed by the study, a person's affect was deemed to be the single strongest indicator of whether that person had been trafficked, particularly where that reaction was one of fear and reluctance to cooperate with law enforcement. ${ }^{140}$ This imprecise approach is likely to result in the rejection of the accounts of individuals who may self-identify as trafficking survivors, but who do not conform to the image or conduct expected. Conversely, for individuals who do not identify as trafficked, law enforcement officials may arrest and detain them as material witnesses or even as offenders. ${ }^{141} \mathrm{~A}$ surprising number of local law enforcement officials interviewed for a research study indicated that they did not recognize human trafficking as a problem in their community at all, ${ }^{142}$ increasing the likelihood that survivors will not be believed even if they disclose their victimization.

This treatment of trafficking survivors as "victim-offenders"somewhere between victims of gendered crimes like domestic violence and offenders like sex workers or undocumented immigrants ${ }^{143}$ - blurs the distinction between state responses of protection and punishment. Law enforcement agencies are not the only ones to struggle with how to categorize survivors, as service providers frequently rely on similar mechanisms in their efforts to identify survivors and respond to their

138. See Roe-Sepowitz et al., supra note 19, at 894.

139. DITMORE, supra note 47 , at 37.

140. FARRELl ET AL., Ne. UNIV. INST. ON RACE AND JUSTICE, UNDERSTANDING AND IMPROVING LAW ENFORCEMENT RESPONSES to HuMAN TRAFFicking 76 (2008), https://www.ncjrs.gov/pdffiles1/nij/grants/222752.pdf.

141. See id. at 45.

142. See id.

143. See Musto, supra note 78 , at 4. 
needs. ${ }^{144}$ One anti-trafficking advocate who runs a shelter for youth who have experienced trafficking gave a conflicted response:

[W] can't treat [the kids] like typical victims of crime who come to you wanting to help ... . If we don't have a way to keep them safe, they're just going back to the streets. So right now, that's juvenile hall and ankle monitors. If we take that away from law enforcement, if we say, 'okay, we're going to do safe harbor law, and that means none of these children can be taken to juvenile hall or ankle monitored at all,' then the question is, what are we going to do? ${ }^{145}$

In addition to rejection by state, federal, and local law enforcement, survivors may encounter rejection in further legal proceedings. Testifying in a trafficking case can be an arduous process even for witnesses who are inclined to cooperate. ${ }^{146}$ In a study of the first generation of state trafficking prosecutions, prosecutors expressed concerns about inconsistencies in survivors' statements, which made for weak cases before judges and juries. ${ }^{147}$ Frequently, there was insufficient corroborating evidence in these cases to back witness testimony, which put pressure on the survivor to testify and conform to an image of credibility. ${ }^{148}$ This may contribute to a survivor's anxiety about whether he or she will be believed.

Survivors who are undocumented or have only temporary immigration status may face further challenges to their testimony in court due to a form of immigration relief intended to protect witnesses. Law enforcement agencies can certify that an individual has cooperated with an investigation into trafficking or other significant crimes, making that person eligible for a $\mathrm{T}^{149}$ or $\mathrm{U}^{150}$ visa. While these visas are undeniably beneficial for victim-witnesses seeking to regularize their immigration status, they can also serve as the basis for accusations that the victimwitnesses have motives to provide false or exaggerated information to law

144. See id.

145. Id. at 5 .

146. See, e.g., Mary Fan, Adversarial Justice's Casualties: Defending Victim-Witness Protections, 55 B.C. L. REv. 775 passim (2014) (describing the traumatizing effects of adversarial proceedings on victim-witnesses, particularly in cases involving violence and abuse); Hussein Sadruddin et al., Human Trafficking in the United States: Expanding Victim Protection Beyond Prosecution Witness, 16 STAN. L. \& PoL'Y ReV. 379, 396 (2005) (describing the reporting and witness preparation requirements for victim-witnesses in trafficking cases).

147. Farrell et al., supra note 130 , at 55.

148. Id.

149. 8 U.S.C. $\S 1101(a)(15)(T)(2012) ; 8$ C.F.R. $\S 214.11$ (2017).

150. 8 U.S.C. $\S 1101(\mathrm{a})(15)($ U) $; 8$ C.F.R. $\$ 214.14$ (2017). 
enforcement. ${ }^{151} \mathrm{~A}$ judge or jury may believe that the individual was pressured into law enforcement cooperation to obtain a visa. ${ }^{152}$ Accordingly, a witness's immigration status, and any potential immigration law violations, become the legitimate subject of crossexamination for purposes of impeachment. ${ }^{153}$

\section{B. Degradation}

\section{Degradation as Emotional Abuse}

Mills describes degradation as behavior in which a batterer publicly humiliates or criticizes a battered woman. ${ }^{154}$ This abuse affects a victim's sense of self-worth and dignity. For both domestic violence and trafficking victims, cruel or degrading treatment, humiliating criticism, and isolation are means of instilling fear and weakening self-esteem. ${ }^{155}$ The work itself in trafficking situations-forced sex work or other difficult physical labor, often for long hours and little pay-is also degrading in and of itself. The lack of autonomy over one's own body, often to the point of pain, can itself be a debasing experience. ${ }^{156}$ There may be many aspects of a trafficking situation that similarly degrade an exploited victim, including violence and rape, limited personal space and privacy, and deprivation of basic needs. ${ }^{157}$

151. See Michael Kagan, Immigrant Victims, Immigrant Accusers, 48 U. MICH. J.L. REFORM 915, 945 (2015).

152. Id. at 950 .

153. Id.

154. Mills, supra note 3, at 589.

155. Roe-Sepowitz et al., supra note 19, at 889; see also OWENS ET AL., supra note 21, at 80,81 (discussing (1) a finding that 82 percent of labor trafficking survivors surveyed experienced demoralizing treatment as part of their exploitation, and (2) examples of trafficking victims being called "cockroaches" or "burros," as well as an incident of a worker being yelled at and publicly humiliated for wasting a paper towel).

156. Motus, supra note 119 , at 38 ; see also OWENS ET AL., supra note 21 , at 8 (referencing survey responses from live-in domestic workers, 36 percent of whom reported abuse, 25 percent of whom reported getting less than five hours of sleep at night, and 31 percent of whom reported that they were unable to communicate privately with friends and family).

157. See, e.g., Motus, supra note 119, at 37; see also OWENS ET AL., supra note 21 , at 8,80 (citing a study in which one in ten respondents reported being sexually harassed and/or a victim of violence within the previous two months, and also citing a finding that 80 percent of labor trafficking survivors reported denial of pay, almost 42 percent reported not receiving meal breaks, over 29 percent reported lack of access to safe water or toilet facilities, 80 percent reported that their travel to work was controlled, 50 percent reported that the victim lived at the work site, and over 84 percent reported deprivations). 
2. Degradation in State Interventions: Police Misconduct and Forced Testimony

People's lived experiences can reinforce threats made in abusive and coercive situations. In the context of trafficking, it is also not unusual for survivors to be degraded in interactions with the criminal justice system, particularly if they are viewed as offenders. The workers interviewed in the Sex Worker Project survey, for example, described a number of upsetting experiences, including being insulted, ${ }^{158}$ arrested and detained or imprisoned, ${ }^{159}$ hurt, ${ }^{160}$ and humiliated ${ }^{161}$ by law enforcement officers. There are also anecdotes of misconduct by law enforcement, particularly local police, who are bought off by establishment managers to not arrest workers, or who engage in paternal, sexualized, or other boundarycrossing behavior with victim-witnesses. ${ }^{162}$ Jennifer Musto reports that, in her interviews with juvenile sex trafficking survivors, all but one interviewee reported some type of punitive interaction with law enforcement, including being "questioned, handcuffed, placed in a juvenile detention facility without any charges against them, having cell phones searched, and feeling used, disrespected, and manipulated by law enforcement," even in the absence of a formal arrest or charge. ${ }^{163}$ While in police custody, survivors may be subjected to poor conditions in detention, including being chained, subjected to verbal harassment by law enforcement officers, and forced to remain undressed for long periods of time. ${ }^{164}$

158. DITMORE, supra note 47, at 26. One worker described the following:

When were [sic] in the hotel being interviewed, there were insults. I had to tell them how I got here, that I had to come here on foot, and explain again, once I'd already done it, and they didn't believe me. Then after all that began the insults. They started to generalize, saying that you guys come to this country muertas de hambre [pitifully poor people, literally 'dying of hunger'] -it is a term in Mexico that is not a pretty thing to say about someone. It means that we come here to Id. take something that this country has.

159. Id. at $26,29,32,35$.

160. Id. at 27 (describing how one of the workers interviewed had been pistol-whipped by an officer and had subsequently passed out from the blow).

161. Id. at 7. A worker recounted:

When I woke up, then I saw people in uniforms. I was passed out for less than a minute. I was struck in the head really hard. I woke up because someone was picking me up. It was a female officer and she opened up my skirt and revealed Id. my undergarments in front of everyone to see if I was hiding anything on me.

162. FARRELL ET AL., supra note 140 , at $43-44$.

163. MUSTO, supra note 78 , at 102.

164. PHILLIPS ET AL., supra note 134, at 18 (citing People ex rel. Maxian v. Brown, 561 N.Y.S.2d 418, 422 (N.Y. App. Div. 1990), aff'd, 570 N.E.2d 223 (N.Y. 1991)). 
Aside from intentionally degrading treatment, more routine experiences within the criminal justice system can be degrading and humiliating to survivors. Specifically, Mills observes in the domestic violence context that survivors are degraded by the experiences of being forced to testify against their will or having their testimony discredited in court. ${ }^{165}$ Trafficked individuals may similarly be pressured to testify against their will. Survivor-centered approaches sometimes describe such testimony as an empowering experience, but the adversarial nature of these proceedings can be deeply traumatic for victim-witnesses. ${ }^{166}$ Advocates point out that such testimony sometimes comes at the expense of the safety of the survivor and his or her family. ${ }^{167}$ Survivors may also feel uncomfortable making disclosures to prosecutors, particularly where they may also be subject to prosecution for wrongdoing even though they are victims. ${ }^{168}$

For immigrant survivors of trafficking who might benefit from immigration relief associated with a trafficking claim, there may be implicit pressure to cooperate even where victim-witnesses are not compelled to do so. In order to be eligible for a $\mathrm{T}$ or $\mathrm{U}$ visa, the affected individual is generally required to be helpful to law enforcement through the duration of the case. ${ }^{169}$ This ongoing "helpfulness" requirement plays a similar role to the mandatory arrest, compelled testimony, and no-drop prosecution policies that used to define the criminal justice response to domestic violence. ${ }^{170}$ Just as in the domestic violence context, a witness may recant testimony or refuse to cooperate to control the outcome of a case and perhaps protect a family member. ${ }^{171}$ But whereas the law has adapted to afford domestic violence survivors alternatives to criminal prosecution of their abusers, such as civil protection orders, trafficking victims do not yet enjoy access to legal and physical protections that do not entail cooperation with and assistance to law enforcement. ${ }^{172}$

165. Mills, supra note 3, at 590-91.

166. See generally Fan, supra note 146.

167. MUSTO, supra note 78, at 106; Aya Gruber, A "Neo-Feminist" Assessment of Rape and Domestic Violence Law Reform, 15 J. GENDER, RACE \& JUST. 583, 599-600 (2012); see also Epstein, supra note 1, at 1867 (describing similar consequences as the result of forced prosecution in domestic violence cases).

168. Gruber et al., supra note 2, at 1375.

169. Victims of Trafficking and Violence Prevention Act of 2000, Pub. L. No. 106386, § 1513(a)(2)(A), 114 Stat. 1464, 1533 (codified as amended at 8 U.S.C. $§ 1101$ (2012)); see also Salima Khakoo et al., Advanced Issues in T and U Visas 2 (unpublished manuscript), https://cliniclegal.org/sites/default/files/1._advanced_issues_for_ts_and_ us.pendleton_1.pdf.

170. Kagan, supra note 151, at 962.

171. Id. at 944 .

172. Chacón, supra note 48 , at 1627. 
Beyond the concern for survivor autonomy and choice, advocates argue that the concern for victims only as witnesses ignores the critical needs of survivors and reduces them to "pieces of evidence" in the criminal justice system. ${ }^{173}$ Even in the context of New York's Human Trafficking Intervention Courts, which are intended to be more survivorcentered, defense attorneys have indicated that "defendants worry that disclosure may place them in danger and are wary of being coerced into cooperation with law enforcement" or prompt additional unwanted intervention by the court, such as mandated appearances or therapy, which are imbued with judgment about a client and his or her lifestyle. ${ }^{174}$ Public defender Kate Mogulescu, who frequently represents trafficking survivors, says that for many of her clients the experience of being a witness is often "worse than being charged with a crime." 175

\section{Terrorizing}

\section{Terrorizing as Emotional Abuse}

Mills defines "terrorizing" in the domestic violence context as acts by the batterer that cause the victim to be afraid or anxious. ${ }^{176}$ Physical violence, or the threat of physical violence, can exist in both the context of domestic violence and trafficking. ${ }^{177}$ As previously discussed, such threats are often part of a dynamic of coercive control. ${ }^{178}$ Terrorizing can also include the exploitation of a victim's vulnerabilities, including age, competence, limited English proficiency, and immigration status. ${ }^{179} \mathrm{~A}$ trafficker or abuser may also make threats to withhold support, ${ }^{180}$ harm a

173. MUSTO, supra note 78 , at 105-06.

174. Gruber et al., supra note 2, at 1375.

175. Symposium, supra note 97 , at 514 .

176. Mills, supra note 3, at 591.

177. See, e.g., Roe-Sepowitz et al., supra note 19, at 896. Roe-Sepowitz et al. described various types of violence:

[I]t has been reported by both groups to include resulting broken bones, sexual violence, bruises, head injuries, mouth and teeth injuries, stab wounds, vaginal pain and bleeding. Similar to battering, sex trafficking victims reported frequently being struck in the face and head resulting in face, head, mouth and teeth injuries.

Id. (citations omitted); see also OWENS ET AL., supra note 21 , at 80,81 ((1) finding that 82 percent of respondents in labor trafficking cases experienced threatened or actual violence as part of coercion, and (2) citing examples of survey responses, including reports of employers carrying, displaying, and discussing weapons; employers shooting and killing animals in front of the workers; and an incident in which an employer's son "bragged about 'going hunting' for workers who tried to leave the camp").

178. See Roe-Sepowitz et al., supra note 19, at 896.

179. NAT'L HuMAN TRAFFICKING Res. CTR., supra note 52, at 1.

180. Roe-Sepowitz et al., supra note 19, at 891. 
victim's children or family, ${ }^{181}$ or report an individual to the police or immigration officials ${ }^{182}$ to assert control and instill fear in victims.

2. Terrorizing in State Interventions: Raids and Compulsion to Cooperate

Many aspects of law enforcement intervention can inspire similar fear and anxiety. A common experience of terrorizing in the state intervention context comes from interaction with law enforcement through their use of raids. ${ }^{183}$ Raids are uniformly described as terrifying experiences, even for individuals who have had positive relationships and interactions with law enforcement. ${ }^{184}$ A National Sex Worker Project Study also found that, although individuals may be removed from dangerous, exploitative, or coerced situations, many interviewees reported being "frightened, confined, and sometimes even bullied" in their interactions with law enforcement. ${ }^{185}$ There are multiple stories of individuals being arrested, interrogated, and threatened with deportation, without access to attorneys or other supportive services. ${ }^{186}$ These raids are often more traumatizing than the trafficking or exploitation experiences themselves. ${ }^{187}$ These raids are more likely to be experienced by survivors as terrorizing if these interventions target marginalized communities, such

181. Id. at 892 ; see also OWENS ET AL., supra note 21 , at 71 . Owens et al. cite the survey response of a victim service provider, who said:

So in this particular situation where the workers were going back to Peru every year, they were brought back with the sort of implicit understanding that if they didn't come back every year, they wouldn't find their families in their home country because the traffickers had connections in the military in their home country.

OWENS ET AL., supra note 21, at 71.

182. Roe-Sepowitz et al., supra note 19, at 892.

183. See, e.g., Saunders, supra note 58 , at 352.

184. See, e.g., DITMORE, supra note 47 , at 28 . In this excerpt, "Jin" describes "the people from immigration" as "pretty nice," but said she was afraid to identify her trafficker when she was being questioned, because that person "said I shouldn't tell the police anything and not to go back to court because she knew a lot of people in the police and only bad things would happen to me." Id. "Jin" later concludes, "A better way to help leave my situation would be anything that didn't involve the police." Id.

185. Id. at 11 .

186. See, e.g., Elizabeth Bernstein, Woodrow Wilson Int'l Ctr. for Scholars, From "Prostitution" to the "Traffic in Women": Political Implications of the (Re)emergence of a Discourse, in RETHINKING HUMAN TRAFFICKING, supra note 129, at 12, 14 (discussing the Operation Bad Neighbor raid); Panel on Sex Trafficking, 5 U. MIAMI RACE \& SOC. JUST. L. REV. 445, 450-51(2015) (featuring the comments of Cyra Choudhury, Aziza Ahmed, Sienna Baskin, and Sandy Skelaney on the mass arrest of sex workers during the 2014 Super Bowl in New Jersey); David Rosenzweig \& K. Connie Kang, Raids on Brothel Rings Net 45 Arrests, L.A. TIMES (July 2, 2005), http://articles.latimes.com/ 2005/jul/02/local/me-smuggling2 (discussing the Operation Guilded Cage raid).

187. Panel on Sex Trafficking, supra note 186, at 451. 
as minority neighborhoods or locales for trans sex workers, where individuals are more likely to have negative experiences with police. ${ }^{188}$ Untargeted arrests in immigrant communities or raids on worksites can have similar terrorizing effects in immigrant communities. ${ }^{189}$

Mills notes that the state may also terrorize a survivor by serving a subpoena and forcing him or her to testify. ${ }^{190}$ This experience is not only humiliating, as previously described, but may also put the victim's life in danger. ${ }^{191}$ Individuals subject to trafficking may also be afraid to disclose their circumstances for fear of repercussions from their trafficker or abuser. ${ }^{192}$ Victims may also fear the consequences of disclosing their experiences or testifying against their employers, especially where traffickers have threatened the survivor with arrest, deportation, or harm to others, and who may be seen as having wealth and other means to leverage the justice system or extract extrajudicial revenge. ${ }^{193}$

\section{Social Isolation}

\section{Social Isolation as Emotional Abuse}

In the domestic violence context, according to Mills, social isolation occurs when the batterer discourages the victim from pursuing social activities. ${ }^{194}$ This may include preventing visits to friends or family or preventing socialization through work. ${ }^{195}$ Isolation and dominance can include taking victims out of their homes or geographic areas so they are disoriented or so their support systems are severed. ${ }^{196}$ Other survivors reported that their traffickers controlled who they spent time with ${ }^{197}$ and who they could call on the phone. ${ }^{198}$

Disorientation and isolation are also common in the labor trafficking context. Over 84 percent of labor trafficking survivors surveyed in an

188. See, e.g., Donna Coker, Crime Control and Feminist Law Reform in Domestic Violence Law: A Critical Review, 4 BUFF. CRIM. L. REV. 801, 808-11 (2001); Symposium, supra note 97, at 503; Weissman, supra note 77, at 401.

189. OWENS ET AL., supra note 21, at 6.

190. Mills, supra note 3, at 590.

191. Bailey, supra note 105, at 1796; Mills, supra note 3, at 590-91.

192. Roe-Sepowitz et al., supra note 19, at 890; see also Verhoeven et al., supra note 28 , at $59-61$.

193. See, e.g., OWENS ET AL., supra note 21, at 38 (citing the response of an employee who was afraid of reporting his employer for labor violations, saying, "They were telling us they are very influential people. They know cops. They know law enforcers. The owner is a well-known judge in [city]. One of the guys who managed us ran for mayor").

194. Mills, supra note 3, at 591.

195. Id.

196. Roe-Sepowitz et al., supra note 19, at 889.

197. Verhoeven et al., supra note 28 , at 57-58.

198. Id. at 58. 
Urban Institute Justice Police Center study reported that their employers isolated them and prevented them from seeking alternatives. ${ }^{199}$ Workers may also be moved from location to location and face restricted contact with people not on the worksite, ${ }^{200}$ may be denied a key to the house so they cannot go out, ${ }^{201}$ or may be told they cannot speak their native language at work. ${ }^{202}$ Economic dependence and abuse also play a role in domestic violence as a way of isolating a victim and forcing dependence on the abuser. ${ }^{203}$

2. Social Isolation in State Interventions: Undermining Support Systems

Beyond the context of immigration, forcing individuals to testify against their abusers and traffickers in court may sever critical social ties in a victim's life. However, trafficking survivors, like domestic violence survivors, may fear the consequences of state-imposed separation over the fear of reprisal from the primary aggressor. Separation may leave a survivor without financial and social support, perhaps indefinitely or permanently, and leave the survivor estranged from her community for reporting the aggressor. ${ }^{204}$

Some experts argue that trafficking survivors may suffer greater isolation than domestic violence survivors as a result of leaving their situation. ${ }^{205}$ Roe-Sepowitz et al. note that sex trafficking in particular involves "initiation into a uniquely specific and isolated culture," with its own language and hierarchy that can make it difficult to leave. ${ }^{206} \mathrm{Criminal}$ records, ${ }^{207}$ limited social connections, low English-language proficiency,

199. OWENS ET AL., supra note 21, at 83.

200. See, e.g., U.S. Dep't OF Health and Human ServS., Labor Trafficking FaCt SHEET 1 (2012), https://www.acf.hhs.gov/sites/default/files/orr/fact_sheet_labor_ trafficking_english.pdf; see also OWENS ET AL., supra note 21, at $8 \overline{\mathbf{1}}$.

201. OWENS ET AL., supra note 21, at 81 .

202. Id.

203. See generally Margo Lindauer, "Please Stop Telling Her to Leave." Where Is the Money: Reclaiming Economic Power to Address Domestic Violence, 39 SEATTLE U. L. REV. 1263 (2016).

204. GOODMARK, supra note 24 , at 103.

205. See, e.g., Roe-Sepowitz et al., supra note 19, at 893-94.

206. Id.

207. See, e.g., Philuips ET AL., supra note 134, at 20-21, 24-25. Phillips et al. highlighted the story of Maria:

I have worked many different jobs since I stopped working in prostitution, but it is always hard to find work that pays enough for me to meet my expenses and care for my children. ... I completed a program to be certified as a home health care attendant. As soon as I received the certification, I submitted an application to be listed by a home health care agency, but they rejected my application because of my criminal record. I believe a big reason I have had such a hard time 
and lack of work authorization may also make it particularly difficult to find alternative employment opportunities. Individuals with a history of drug use, which is not uncommon for survivors of trafficking, may also be ineligible for public financial assistance. ${ }^{208}$

State programs often use resources as incentives for individuals who cooperate with law enforcement investigations, and individuals without social and economic support systems are more likely to experience pressure to comply in order to meet their basic needs. Mills argues that this dynamic replicates a survivor's dependence on her abuser because, "[1]ike the batterer, the state rejects the battered woman for her refusal to comply with its conditions and thereby isolates her." 209 Cooperation as a witness is often accompanied by referral for supportive services such as victim advocacy, legal representation, and referrals for resources. ${ }^{210}$ As in an abusive situation, the survivor may feel compelled to cooperate for fear of losing access to much-needed support.

For example, one attorney interviewed in the Sex Worker Project described the situation of a client who decided that she did not want to be involved in the legal case anymore and she wanted to return home, and law enforcement responded by detaining her and taking away her immigration benefits. ${ }^{211}$ A law enforcement employee interviewed in the same study indicated that Immigration and Customs Enforcement issues notices to appear before immigration court, triggering removal proceedings against witnesses "because it keeps them involved in the process."212 Cooperation with law enforcement may also require individuals to avoid friends, family, or other members of their social support network who are involved in the trafficking enterprise. ${ }^{213}$ There is a shortage of resources-particularly for labor trafficking survivors as well as adult women, cisgender boys, and transgender people who might

finding and keeping a job is because of the prostitution-related criminal convictions that are on my record.

Id.

208. AnNa-Louise Crago, Open SoC'y Inst., OUR Lives Matter: SeX Workers

UNITE FOR HEALTH AND RIGHTS 11 (2008), https://www.opensocietyfoundations.org/ sites/default/files/Our\%2520Lives $\% 2520$ Matter $\% 2520 \% 2520$ Sex $\% 2520$ Workers $\% 2520$

Unite $\% 2520$ for $\% 2520$ Health $\% 2520$ and $\% 2520$ Rights.pdf.

209. Mills, supra note 3, at 591-92.

210. See generally U.S. Dep't OF Health and Human Servs., Services Available to Victims of Human Trafficking: A Resource Guide for Social SERvices Providers (2012), https://www.acf.hhs.gov/sites/default/files/orr/traffickingservices_ 0 .pdf (outlining federal and state services available to trafficking survivors).

211. FARRELL ET AL., supra note 140, at 52.

212. Id. at 37.

213. AGUSTín, supra note 28, at 114; Broad, supra note 29, at 1060-61. 
be subject to trafficking-that makes it more difficult for people to support themselves after leaving an exploitative situation. ${ }^{214}$

\section{E. Missocialization}

\section{Missocialization as Emotional Abuse}

Mills describes missocialization in the domestic violence context as occurring "when the batterer coerces the battered woman to become involved in antisocial behavior or illegal activities." 215 She describes scenarios in which an abused woman is coerced into committing crimes. ${ }^{216}$ In the trafficking context, such missocialization could also involve illegal activities such as prostitution, substance abuse, ${ }^{217}$ or being forced to enter the United States unlawfully. ${ }^{218}$ The covert and often illegal nature of sex work also makes it more difficult for victims to come forward, even to service providers and advocates. ${ }^{219}$

2. Missocialization in State Interventions: Solidifying Relationships to Abusers

Mills observes that, in the domestic violence context, forcing a survivor to testify against a partner may "inadvertently cause her to realign with him rather than face the state's violence."220 This may undermine the objectives of the prosecution, potentially jeopardize the survivor's safety, or expose a survivor to potential charges for aiding and abetting in other offenses. $^{221}$

In the context of human trafficking, many scholars have noted that the experience of being new in the destination country and the perceptions of hostility against migrants already increase the dependency of individuals on their traffickers. ${ }^{222}$ Although workplace raids and the jailing of trafficking suspects appear to be in the best interest of survivors, it is not uncommon for survivors to intend to return to the trafficking scheme as a source of familiar connection and financial support. ${ }^{223}$ Immigration

214. MUSTO, supra note 78 , at 145.

215. Mills, supra note 3 , at 592.

216. Id. at 594.

217. See, e.g., Megan Helton, Human Trafficking: How a Joint Task Force Between Health Care Providers and Law Enforcement Can Assist with Identifying Victims and Prosecuting Traffickers, 26 HEALTH MATRDX 433, 445 (2016).

218. OWENS ET AL., supra note 21 , at 72.

219. Roe-Sepowitz et al., supra note 19 , at 888.

220. Mills, supra note 3 , at 593.

221. Id.

222. Musto, supra note 7 , at 283.

223. Srikantiah, supra note 86 , at 200 . 
and criminal law enforcement techniques also reinforce a trafficker's threat that, if individuals come forward, they are likely to be arrested or deported. ${ }^{24}$ These factors all contribute to the likelihood that a survivor will align himself or herself with the trafficker and refuse to disclose information or testify at trial.

The law itself also poses obstacles to certain immigrant survivors escaping trafficking. For individuals who lack regular immigration status, exploitation often involves leveraging the lack of authorization to work or be lawfully present in the country. The Urban Institute Justice Policy Center survey reports that labor trafficking victims were told that their phone calls were being monitored by police, or that employers would stop processing immigration paperwork if victims left. ${ }^{225}$ Certain categories of immigrant workers - including agricultural and forestry guest workers, ${ }^{226}$ domestic workers for diplomats, ${ }^{227}$ and foreign government officials ${ }^{228}$ also have visas tied to a particular employer, and are hence more susceptible to threats that they will be in the United States without permission if they leave the trafficking situation. In this way, immigration law keeps guest workers and certain domestic workers tied to potentially abusive employers. These workers may be afraid to disclose their situation, especially to state and local police who might share their information with immigration enforcement officers. ${ }^{229}$

224. Haynes, supra note 129, at 17; Jennifer M. Chacón, Human Trafficking, Immigration Regulation and Sub-Federal Criminalization, 20 NEW CRIM. L. REV. 96, 116 (2017).

225. OWENS ET AL., supra note 21 , at 83.

226. See 8 U.S.C. § $1101(\mathrm{a})(15)(\mathrm{H})(\mathrm{ii})(\mathrm{a})-(\mathrm{b})(2012)$.

227. See id. $\$ 1101(\mathrm{a})(15)(\mathrm{A})(\mathrm{iii})$.

228. See id. $\$ 1101(\mathrm{a})(15)(\mathrm{G})(\mathrm{iv})$.

229. U.S. Immigration and Customs Enforcement (ICE) implemented Secure Communities on January 22, 2013. Secure Communities-Overview, U.S. IMMIGRATION \& Customs ENF'T, https://wwwiice.gov/secure-communities (last visited July 9, 2017). The program requires state and local law enforcement to provide biometric information. Id. ICE's operational posture under Secure Communities was temporarily suspended by Department of Homeland Security (DHS) policy from November 20, 2014 through January 25, 2017. Id. In 2013, due in part to the response to the Secure Communities program, a new Memorandum of Agreement was negotiated for the $\$ 287(\mathrm{~g})$ program with local law enforcement agencies pursuant to the provision in the Immigration and Nationality Act that permits the DHS to deputize selected state and local law enforcement officers to enforce federal immigration law. See Illegal Immigration Reform and Immigrant Responsibility Act of 1996, Pub. L. No. 104-208, $\S 133,110$ Stat. 3009, 3009-563 (codified as amended at 8 U.S.C. $\$ 1357(\mathrm{~g})(1)(2012)$ ) (amending $\S 287$ of the Immigration and Nationality Act); Delegation of Immigration Authority Section $287(\mathrm{~g})$ Immigration and Nationality Act Fact Sheet, U.S. IMMIGRATION \& CUSTOMS ENF'T, (Feb. 14, 2014), http://www.aila.org/File/DownloadEmbeddedFile/51497 (including links to mutually signed agreements with individual agencies as of August 13, 2014). In January 2017, President Donald Trump signed an executive order on border security, calling on the Secretary of the DHS to "immediately take appropriate action to engage with the Governors of the States, as well as local officials, for the purpose of preparing to enter into agreements 


\section{F. Exploitation}

\section{Exploitation as Emotional Abuse}

According to Mills, exploitation occurs in the domestic violence context "when the abuser uses the battered woman to support his lifestyle," sometimes through illegal activity. ${ }^{230}$ Roe-Sepowitz et al. acknowledge that exploitation occurs in the domestic violence context, but note that exploitation plays a unique role in trafficking situations, where the primary objective of the relationship is to profit from exploitation. ${ }^{231}$ Forced prostitution, unauthorized immigration, and fraud are all forms of exploitation that implicate victims in illegal conduct. ${ }^{232}$

2. Exploitation in State Interventions: Prosecuting to "Send a Message"

According to Mills, "[t]he state replicates a batterer's behavior when it 'uses' individual battered women to send a strong message to all batterers," but ironically, "one-dimensional policies often exploit the individual battered woman," particularly when her desires diverge from prosecutorial interests. ${ }^{233}$ In the trafficking context, there is a similar presumption that the arrest and prosecution of traffickers communicates a zero-tolerance policy towards the crime. ${ }^{234}$ Dorchen Leidholt, a feminist activist from the Coalition Against the Traffic in Women, speaking at the United Nations Commission on the Status of Women, stated that "[t]rafficking is like domestic violence: the only thing that prevents

under $[\S] 287(\mathrm{~g})$ of the INA." Exec. Order No. 13,767, 82 Fed Reg. 8,793, 8,795 § 10(a) (Jan. 30, 2017). While the relationship between state and local law enforcement and immigration enforcement agencies is still developing, the high-profile instances of police cooperation with ICE still serve as a potential deterrent for survivors reporting their exploitation to law enforcement, especially where employers emphasize their connections with the police.

230. Haynes, supra note 129, at 17.

231. Roe-Sepowitz et al., supra note 19, at 892.

232. See supra note $219-20$ and accompanying text.

233. Mills, supra note 3, at 593.

234. See, e.g., Luis CdeBaca, Woodrow Wilson Int'l Ctr. for Scholars, Human Trafficking and the Law in the United States, in RETHINKING HUMAN TRAFFICKING, supra note 129 , at 6,13 . For example, CdeBaca explains:

To put it bluntly, trafficking in persons is a crime. It is a crime akin to murder and rape and kidnapping. We have to confront it not just by addressing root causes that are so far away from the realities of the trafficker and those they enslave, but by using all of our tools. And so the UN Protocol mandates criminalization of trafficking in persons, and the U.S. laws are very focused on law enforcement, because a policy solution to a heinous crime problem must Id. involve freeing the victims and punishing their tormentors. 
recurrence is fear of arrest." 235 The federal government regularly uses the example of arrest and prosecution as proof that the United States is tough on the crime of trafficking: the FBI website showcases dozens of press releases on arrests of suspects in trafficking rings, ${ }^{236}$ the U.S. Department of Justice emphasizes successful prosecutions of trafficking cases, ${ }^{237}$ and the U.S. Department of State highlights trafficking arrest and prosecution efforts in its assessment of the United States' rank in the annual Trafficking in Persons Report. ${ }^{238}$ Raids, prosecutions, and criminalization at the state and local level may similarly receive high-profile coverage to communicate that the government is effectively responding to the global problem of human trafficking. ${ }^{239}$

Courts may also use judicial intervention in a particular way to send a message to victim-offenders. Prosecution of trafficking victims, even in "therapeutic" alternative venues like the Trafficking Intervention Courts, is often supported by a state rationale that survivors need to be rescued from their trafficking situations. ${ }^{240}$ Musto points out that this practice of "arresting to rehabilitate" has historical roots in the juvenile justice system. ${ }^{241}$ Judge Camacho, an early supporter of the Human Trafficking Intervention Courts in New York, has indicated his belief in the relationship between coercive control exercised by pimps and "poor choices" by those facing prostitution charges. ${ }^{242}$ Where survivors become defendants in trafficking cases, even supportive services become intertwined with or secondary to law enforcement goals, ${ }^{243}$ particularly when the services are prescribed by a court.

235. Bernstein, supra note 106, at 52. This language echoes the oft-cited Minneapolis Domestic Violence Experiment, which found that arrests had a deterrent effect for domestic violence offenders. See SHERMAN \& BERK, supra note 69, at 6-7. The study has since been criticized for both its methodology and conclusions, and subsequent studies have challenged the results. See, e.g., Aya Gruber, The Feminist War on Crime, 92 IowA L. REV. $741,802-03$ (2007).

236. See, e.g., FBI Announces Results of Operation Cross Country X, FBI, (Oct. 7, 2016), https://www.fbi.gov/news/pressrel/press-releases/fbi-announces-results-ofoperation-cross-country-x.

237. See Criminal Section Selected Case Summaries, U.S. DEP'T OF JUSTICE, CIVIL RIGHTS DIV., http://www.justice.gov/crt/about/crm/selcases.php\#humantrafficking.

238. U.S. DeP'T OF STATE, 2015 TRAFFicking IN PERSONS RePORT 352 (2015), http://www.state.gov/documents/organization/245365.pdf (stating that, in the justification for the United States' Tier 1 ranking, "[t]he U.S. government fully complies with the minimum standards for the elimination of trafficking. The federal government continued to investigate and prosecute both sex and labor trafficking, sustaining high prosecution rates").

239. See Chacón, supra note 48, at 1628.

240. Musto, supra note 78, at 13-14.

241. Id. at 39 .

242. Gruber et al., supra note 2, at 1393.

243. Musto, supra note 78, at 21. 
Although trafficking intervention courts have been seen as positive alternatives to criminal prosecution of prostitution cases, defendants often experience (and sometimes resent) more court intrusion in their lives. ${ }^{244}$ Gruber et al. observe that remedies used by the court, such as mandated therapy, may still be coercive in that judges and prosecutors may pressure defendants to accept treatment-based sentences. ${ }^{245}$ The interviews with Trafficking Intervention Court defense attorneys reflect the belief that individuals before the court are "re-victimized by judicial acts of authority and mandated participation in court-ordered programs."246

One defense attorney shared an experience where a Human Trafficking Intervention Court judge was very focused on getting services for her client, but then offended the client by saying that she would receive fifteen days in jail if she did not complete the services. ${ }^{247}$ Even proponents of the Human Trafficking Intervention Courts struggle with how to address the perception among defendants that such treatment is therapeutic rather than punitive. ${ }^{248}$ The tension between survivor-centeredness and law enforcement efforts becomes even more apparent in these problemsolving courts where prosecutors worry that an inability to increase sentences for subsequent offenses will inhibit their ability to send a message to the wider community regarding prostitution activities. ${ }^{249}$

\section{G. Emotional Unresponsiveness}

\section{Emotional Unresponsiveness as Emotional Abuse}

Mills describes emotional unresponsiveness as a batterer detaching from a partner or ignoring her. ${ }^{250}$ She observes that an abuser may only interact with a victim "when it is absolutely necessary," or may fail to offer care and recognition when a victim asks for it. ${ }^{251}$ In the trafficking context, the emotional unresponsiveness is related to exploitation and the lack of concern and feeling for workers. The experience of trafficking is often intentionally dehumanizing. Survivors are often forced to work long hours under difficult conditions, and are afforded little sleep and inadequate food. ${ }^{252}$ The work is generally painful or physically difficult, and is often

244. Gruber et al., supra note 2, at 1367.

245. Id. at 1367-68.

246. Id. at 1367 .

247. Id. at 1367-68 (citing Interview with Zoe Root, Attorney, Bronx Defenders (June $26,2014)$ ).

248. Id. at 1368 .

249. Id. at 1368-69.

250. Mills, supra note 3 , at 594 .

251. Id.

252. OWENS ET AL., supra note 21 , at 81. 
degrading. ${ }^{253}$ Victims often receive no acknowledgement of their basic human needs, including clean and safe living conditions, health care, rest or leisure time, and social connection. ${ }^{254}$ Workers' grievances and pain are often minimized and ignored. ${ }^{255}$

2. Emotional Unresponsiveness in State Interventions: Forced Separation

"In the era of mandatory interventions," writes Mills, "one of the most striking features of the dynamic between state actors and battered women is the state actors' emotional attachment."256 She observes that mandatory intervention policies were striking in that they completely ignored the feelings, preferences, and reactions of the survivors that these policies were intended to protect. ${ }^{257}$ Police would arrest batterers, compel a survivor's testimony, and provide little in the way of emotional and clinical support. ${ }^{258}$

Many critics of domestic violence policy point out that prosecution does not take into consideration the emotional attachment within a relationship and how difficult it might be for a survivor to bear the emotional consequences of a partner's punishment. ${ }^{259}$ Domestic violence policy was initially unconcerned with the relationship between parties in a marriage. ${ }^{260}$ Emotional attachment was often explained as a product of trauma (or "traumatic bonding"), ${ }^{261}$ and separation presented as the necessary therapeutic cure. ${ }^{262}$ Critics argued that the law effectively pathologizes emotional attachments between parties in an abusive relationship, treating love as "a problem to solve."263 Even so, these ideas remain inherent in policies that emphasize separation as necessary for safety. ${ }^{264}$

\footnotetext{
253. Id.

254. Id.

255. Id.

256. Mills, supra note 3, at 594 .

257. Id.

258. Id.

259. See, e.g., GOODMARK, supra note 24, at 98-99; see generally Tamara L. Kuennen, "Stuck" on Love, 91 DENV. U. L. REV. 171 (2013).

260. See William L. Hart, U.S. Dep'T OF Justice, AtTorney General's Task FORCE FINAL REPORT ON FAMILY VIOLENCE 75 (1984), http://files.eric.ed.gov/fulltext/ ED251762.pdf.

261. See, e.g., Megan Annitto, Consent, Coercion, and Compassion: Emerging Legal Responses to the Commercial Sexual Exploitation of Minors, 30 YALE L. \& POL'Y REv. 1, 12-13 (2011).

262. GOODMARK, supra note 24, at 99.

263. Id. at 98 .

264. Id. at $100-01$.
} 
The same emphasis on separation is evident in trafficking prosecutions where individuals are forcibly removed from the situation or are forced to testify against someone to whom they are connected. Survivors and their traffickers are seldom strangers to each other; many have familial, pseudo-familial, or romantic connections. ${ }^{265}$ In some trafficking networks, kinship models are encouraged, including domestic partnerships, mother-daughter dyads, and extended families. ${ }^{266}$ Some female traffickers use their friendship and acquaintance networks for recruitment, often at the urging of male counterparts with whom they are intimately involved. ${ }^{267}$ There is a wide range of experiences among trafficked individuals, and the reality is that some individuals may feel emotional connection, familial obligation, and other complex and potentially competing emotions to those implicated in their trafficking situations. Prosecution may therefore subordinate and devalue a survivor's feelings and preferences in the same way an emotionally unresponsive partner might. ${ }^{268}$

As in the case of domestic violence, where the state intervenes to forcibly separate individuals from their relationships within a trafficking scheme, separation may be unwelcome and may leave a victim more socially vulnerable. Many individuals who do not wish to separate or be complicit in the prosecution of someone with whom they have a relationship will not seek help, in spite of state pressures to do so. One example of a state incentive is the law enforcement cooperation and certification requirements for $\mathrm{T}$ and $\mathrm{U}$ visas. ${ }^{269}$ Even where a survivor may be desperately in need of immigration relief, he or she may be unwilling to assist law enforcement, particularly if an investigation may result in a partner or family member's prosecution and removal from the United States. ${ }^{270}$ Even where a survivor wishes to be separated from a partner, testifying against that person can mean that the person is removed from the United States, unable to provide financially for the survivor or children they have in common. ${ }^{271} \mathrm{~A}$ survivor must therefore weigh his or her

265. See, e.g., AGuStin, supra note 28, at 1. For a comparable analysis of smuggling, see Nassim Majidi, Communities of Smugglers and the Smuggled, OPENDEMOCRACY (Apr. 8,2016 ), https://www.opendemocracy.net/beyondslavery/hsr/nassim-majidi/ communities-of-smugglers-and-smuggled.

266. Warren, supra note 28 , at 114-15, 117-18.

267. See Broad, supra note 29, at 1061; see also Verhoeven et al., supra note 28.

268. See, e.g., Bailey, supra note 105, at 1789-92.

269. See supra note 170 and accompanying text.

270. See Rachel Gonzalez Settlage, Uniquely Unhelpful: The U Visa's Disparate Treatment of Immigrant Victims of Domestic Violence, 68 RUTGERS U.L. REV. 1747, 178384 (2016).

271. GOODMARK, supra note 24, at 102; Bailey, supra note 105, at 1797. 
immigration status needs against the benefits of having emotional, economic, and family support.

\section{H. Close Confinement}

\section{Close Confinement as Emotional Abuse}

Mills discusses close confinement in the domestic violence context as a batterer's way of securing control over a victim. ${ }^{272}$ Roe-Sepowitz et al. describe the practice of "role grooming" for both domestic violence and trafficking victims, essentially, "rules that [victims] know not to break 'or else." 273 Depending on the nature of a trafficking situation, restricting a victim's movements and mobility may also be part of the exploitation and abuse. $^{274}$ In the Urban Institute Justice Policy Center survey of labor trafficking survivors, respondents reported that this control could be physical $^{275}$ or psychological. ${ }^{276}$ It is common for guest workers in the agriculture, hospitality, construction, and restaurant industries to be housed on site or provided with housing by their employers, ${ }^{277}$ meaning that traffickers in these industries often control victims' housing environment. Domestic workers also often live in the homes where they work, and so they are subject to regular monitoring by their employers. ${ }^{278}$

2. Close Confinement in State Interventions: Detention and Incarceration of Victims

Although confinement is often associated with the experiences of trafficking survivors, law enforcement officers may also create conditions of close confinement when they arrest victims as offenders. ${ }^{279}$ Farrell et al. report that survivors were arrested in 59 percent of state-level cases in their study ${ }^{280}$ Individuals can be poorly treated in police custody, especially if they are identified as offenders. The International Women's Human Rights Clinic at the CUNY School of Law details the treatment individuals

272. Mills, supra note 3, at 594.

273. Roe-Sepowitz et al., supra note 19 , at 889.

274. See OWENS ET AL., supra note 21, at 81 (citing examples of employers controlling survivors' housing, transportation, social contacts, and communication with family).

275. See, e.g., id. at 82 (citing example of respondent who described being kept in a barbed-wire compound that was surrounded by armed guards).

276. See, e.g., id. at 90 (citing example of a domestic worker in Saudi Arabia who was told she could not go outside without a burka).

277. Id. at 127 .

278. Id. at 81 .

279. Farrell et al., supra note 130 , at 55-56 (citing arrest as a mechanism to compel victim cooperation with law enforcement and noting the correlation between victim arrest and successful prosecutions).

280. Id. at 56 . 
receive in central booking in New York City while awaiting charges, ${ }^{281}$ including degradation and harassment by officers. ${ }^{282}$

Law enforcement officers may also take survivors into custody to assess their ability to serve as witnesses against individuals involved in trafficking networks. ${ }^{283}$ Detention, interrogation, and the possibility of pressing charges all serve to compel testimony; one prosecutor interviewed for a study on state trafficking cases is quoted as saying, "[y]ou can't get [a trafficking charge] without breaking a few eggs . . . at some point in time you've got to be willing to charge some of these girls with prostitution, or charge some people at a lower level to move up." 284 A report by the International Women's Human Rights Law Clinic at CUNY School of Law highlights a particularly ironic story of a woman who repeatedly pled guilty to prostitution charges at the advice of her attorney, but who avoided going to Riker's Island through the intervention of one of her clients, who happened to be the captain of corrections. ${ }^{285}$

Close confinement of a survivor is often rationalized in trafficking cases as a method of protection. In their observations of the Human Trafficking Intervention Courts in New York, Gruber et al. observed a case in which an individual was detained after she failed to appear in court and was arrested on an additional prostitution charge. ${ }^{286}$ The defendant could not afford the $\$ 2,500$ bail, and thus was detained indefinitely, which also meant that she was separated from her four-month-old child. ${ }^{287}$ This arrest and detention was justified as necessary for the woman's safety, but this harsh result would be unusual and likely deemed unfair for a criminal defendant in a different sort of case. ${ }^{288}$ In the context of the Human Trafficking Intervention Court, "release on bail can actually be inversely related to evidence of trafficking," 289 as in the example of a woman who was subject to pretrial detention as a means of preventing her from returning to an abusive intimate partner. ${ }^{290}$ Ironically, disclosure can

281. PhilliPS ET AL., supra note 134, at 18 (citing Interview with Kate Mogulescu, Supervising Attorney, Trafficking Victims Advocacy Project, Legal Aid Society, in New York City, N.Y. (Apr. 24, 2013)).

282. Id. (citing People ex rel. Maxian v. Brown, 561 N.Y.S.2d 418, 422 (N.Y. App. Div. 1990), aff'd, 570 N.E.2d 223 (N.Y. 1991)).

283. See, e.g., Farrell et al., supra note 130 , at 56.

284. Id.

285. PHILLIPS ET AL., supra note 134, at 19.

286. Gruber et al., supra note 2, at 1357-58.

287. Id.

288. Id. at 1359 .

289. Id. at 1370 .

290. Id. at $1358-59,1370,1375-76$ (describing a case where a defendant disclosed to her treatment team that she had been trafficked by an intimate partner and the prosecutor recommended that she be remanded to jail). Gruber et al. explain: 
prompt a decision within the court to use incarceration in the interest of a survivor's safety, "particularly in instances where there is concern about the defendant's ability to make good choices for herself." 291

In the context of state intervention, individuals identified as witnesses are also regularly held in close confinement by law enforcement. Individuals in the Sex Worker Project Study, for example, describe being confined to hotel rooms for several days of questioning, ${ }^{292}$ being separated from other workers in police cars and at the police station, ${ }^{293}$ being placed in holding ${ }^{294}$ or immigration detention, ${ }^{295}$ being imprisoned, ${ }^{296}$ being denied access to case workers and attorneys, ${ }^{297}$ and being unable to call home or otherwise contact friends and family. ${ }^{298}$

\section{POLICY IMPLICATIONS: RECASTING THE STATE RESPONSE tO HUMAN TRAFFICKING}

Mills makes the case that state intervention, in mirroring the dynamic of abuse, undermines effective relationships with survivors and interferes with their ability to heal and reconnect with others. She argues that a clinical or affective approach by law enforcement agents and prosecutors would better support engagement and trust with victims. ${ }^{299}$ Learning from the progression of the anti-domestic movement, the anti-trafficking movement could benefit from survivor-centered alternatives to criminalization and incarceration.

\section{A. Recognizing the Significance of Relationships and Support Systems}

The lack of resources available for individuals who are vulnerable to exploitation or are seeking to leave an exploitative situation contributes to

The very fact that this HTIC defendant had disclosed trafficking became the specific grounds on which prosecutors sought to put her in jail. She had not committed any additional crime, and had appeared in court when required. The prosecutor and judge's knowledge of [her] experience and abusive relationship set her incarceration in motion.

Id.

291. Id. at 1375.

292. DITMORE, supra note 47, at 25, 32 (discussing interviews with "Marta" and "Lilly").

293. Id. at 27 (discussing interview with "Jin").

294. Id. at 30, 32 (discussing interviews with "Daniela" and "Lilly").

295. Id. at 29 (discussing interview with "Ofelia").

296. Id. at 27, 30 (discussing interviews with "Jin" and "Josefina").

297. Id. at 25-35 (discussing interview with "Leila" and discussing how all of the interviewees describe being interrogated by law enforcement without an attorney or advocate present).

298. Id. at 27, 30-31 (discussing interviews with "Jin," "Josefina," and "Daniela").

299. Mills, supra note 3, at 596. 
the constant presence of trafficking. The lack of affordable housing, employment options, and a social safety net make transition out of trafficking situations extremely difficult, and contribute to the possibility that someone will reenter a trafficking situation in order to obtain that dayto-day sustenance and support. ${ }^{300}$ The anti-trafficking movement must also seriously consider the social support that an individual might sustain through a trafficking situation, including romantic relationships or kinship with individuals implicated in their trafficking.

\section{B. Preserving Survivor Autonomy}

The anti-trafficking movement also has much to learn from the progressive anti-domestic violence movement in its deference to survivor autonomy and in creating meaningful choices for people seeking to leave an abusive situation. In their comparison between domestic violence and sex trafficking, Roe-Sepowitz et al. suggest that trafficking survivors ought to have access to expedient legal remedies, ${ }^{301}$ comparable to protective orders for domestic violence cases. ${ }^{302}$ They concede that these processes would need to be modified to best serve the particular situation of people seeking to leave a trafficking situation, but that such measures might enhance trust and comfort in seeking law enforcement assistance. ${ }^{303}$

A critical aspect of the protective order model is that it need not result in a criminal prosecution unless the other party violates the order; it can also be dropped without consequences. The order allows a victim to stop the abuse and take the opportunity to leave, whether temporarily or permanently. ${ }^{304}$ Not all survivors wish to continue with the criminal process, but the window is valuable for survivors to keep themselves safe in the short term and consider longer-term plans. Roe-Sepowitz et al. also suggest that such measures could be enhanced by provisions of immunity for those who come forward to seek the relief and by safe houses where survivors can stay until the protection order is served. ${ }^{305}$ These measures could ultimately result in greater cooperation with law enforcement, but

300. Abigail Swenstein \& Kate Mogulescu, Resisting the Carceral: The Need to Align Anti-Trafficking Efforts with Movements for Criminal Justice Reform, 6 ANTITRAFFICKING REV. 118, 118-19 (2016).

301. Roe-Sepowitz et al., supra note 19, at 895.

302. For a discussion of protective orders as an alternative to mandatory law enforcement intervention, see Emily J. Sack, Battered Women and the State: The Struggle for the Future of Domestic Violence Policy, 2004 WIS. L. REV. 1657, 1687-89 (2004).

303. Roe-Sepowitz et al., supra note 19, at 895.

304. But see Johnson, supra note 92, at 1138-39 (criticizing the limited definition of "domestic violence" for protective orders); Jeannie Suk, Criminal Law Comes Home, 116 YALE L.J. 2, 16-18 (2006) (highlighting the problematic nature of criminal enforcement of civil protective orders).

305. Roe-Sepowitz et al., supra note 19, at 895. 
as a matter of a survivor's choice. ${ }^{306}$ The emphasis on choice would disrupt the narrative around trafficking victims as passive or subject to the influence of traumatic bonding.

As in the domestic violence movement, prioritizing and promoting access to options for survivors means re-thinking what it means to be survivor-centered. Previously, for domestic violence survivors, this has meant a greater emphasis on "providing services that are voluntary, nonjudgmental, culturally and linguistically appropriate, and that are informed by the priorities and concerns of the client." 307 This may not necessarily be in tension with law enforcement objectives. Freedom Network USA, one group that provides assistance to trafficking survivors, observes that when individuals who have been subjected to trafficking have the opportunity to exercise self-determination, they "tend to regain security, trust and self-sufficiency much more quickly." 308 This ultimately contributes to their ability to serve as witnesses and "make for stronger witnesses in legal cases," whereas they tend to withdraw, withhold, and suffer re-traumatization when deprived of a sense of control. ${ }^{309}$

\section{Undoing the Criminalization Paradigm}

The approaches mentioned above suggest that law enforcement objectives might be best served if they are secondary to the needs of survivors. It can also be argued, however, that survivors are best served where law enforcement objectives and associated punitive methods are removed from the calculus altogether. This rationale is arguably necessary because, in interactions with law enforcement, individuals working in informal and alternative economies are likely to continue to bear some form of criminal liability, even when they are victims.

The reality of labor trafficking is that there will always be the potential to profit from questionable work, and the existing economic system leaves exploited workers open to law enforcement encounters and possible punishment for offenses such as prostitution, substance abuse, and immigration violations. If individuals are to feel free to come forward and expose the conditions of their trafficking, there must be no compulsion and no punitive consequences. This is complicated by law enforcement concerns for the involvement of some survivors in the trafficking networks that victimize others, but perhaps highlights a need to re-envision the

306. But see GoODMARK, supra note 24, at 89-93 (noting that the act of obtaining a protective order can expose someone subjected to abuse to greater danger, that protective orders are not always readily and expediently available, and that these orders can be challenging to enforce).

307. FREEDOM NETWORK, supra note 50, at 2.

308. Id.

309. Id. 
nature of the problem in order to inhibit its propagation. One can also appreciate the need to take trafficking seriously, but these objectives need not result in an approach that pursues prosecution single-mindedly at the expense of victim protection. ${ }^{310}$

This victim-centered paradigm also requires reconsideration of what "victim protection" truly means. Defense attorneys who represent individuals charged with prostitution, for example, are critical of courts' treatment of survivors precisely because it "repackage[s] criminal intervention as welfare." ${ }^{\text {"311 }}$ Similarly, it may be misplaced to describe criminal prosecution and even civil restitution trafficking cases as justice for victims. Some trafficking survivors may benefit from such cases, but turning to civil remedies often leaves clients without representation; conversely, relying on the criminal justice system offers nothing in the way of restitution. ${ }^{312}$ "The abysmal result," Human Trafficking Pro Bono Legal Center founder Martina Vandenberg concludes, "is that defendants get to keep what they stole; victims remain penniless; and under-funded public interest organizations are saddled with the costs of caring for victims." ${ }^{313}$ It is therefore worth considering how the justice system can support survivors in their efforts to make themselves whole, rather than simply meting out punishment that further undermines their interests.

\section{CONCLUSION}

The battered woman's movement has evolved considerably in the effort to create protection and support for domestic violence survivors. There remains deep ambivalence about the role of the state in responding to the needs of survivors, but the law has moved away from the mandatory intervention that Mills describes as state violence by giving survivors more options and supporting their freedom of choice. Trafficking in persons represents a massive social problem with health and safety consequences not unlike those posed by domestic violence. Although there are significant differences between these phenomena, trafficking survivors must preserve themselves in the face of relationship-based harm, coercion, and trauma in similar ways to domestic violence survivors. By acknowledging the ways in which carceral state interventions harm survivors, it is possible to reconsider the role of the state in light of the need to promote survivor autonomy and provide the support necessary for

310. Chacón, supra note 48 , at 1626 .

311. Gruber et al., supra note 2, at 1337.

312. Martina E. Vandenberg, Palermo's Promise: Victims' Rights and Human Trafficking, 6 ANTI-TRAFFICKING REV. 138, 141 (2016).

313. Id. at 140 . 
individuals to make choices that will promote their survival and best interests. 
